\title{
Understanding COVID-19 in Wuhan From the Perspective of Cold-Dampness: Clinical Evidences and Mechanisms
}

\author{
Yujiao Zheng ${ }^{1,2 \dagger}$, De Jin ${ }^{1 \dagger}$, Jiaran Lin ${ }^{2}$, Yuehong Zhang ${ }^{1}$, Jiaxing Tian ${ }^{1}$, Fengmei Lian ${ }^{1 *}$ and \\ Xiaolin Tong ${ }^{1 *}$
}

'Department of Endocrinology, Guang'anmen Hospital, China Academy of Chinese Medical Sciences, Beijing, China,

${ }^{2}$ Graduate School, Beijing University of Chinese Medicine, Beijing, China

\section{OPEN ACCESS}

Edited by:

Bathri Narayan Vajravelu,

MCPHS University, United States

Reviewed by:

Zimple Kurlawala,

National Institutes of Health $(\mathrm{N} / \mathrm{H})$,

United States

Richa Singhal,

University of Louisville, United States

*Correspondence:

Fengmei Lian

Ifm565@sohu.com

Xiaolin Tong

tongxiaolin@vip.163.com

tThese authors have contributed equally to this work

Specialty section:

This article was submitted to Infectious Diseases-Surveillance,

Prevention and Treatment,

a section of the journal

Frontiers in Medicine

Received: 15 October 2020

Accepted: 08 January 2021

Published: 22 February 2021

Citation:

Zheng $Y$, Jin D, Lin J, Zhang Y, Tian J, Lian F and Tong $X$ (2021) Understanding COVID-19 in Wuhan

From the Perspective of

Cold-Dampness: Clinical Evidences and Mechanisms.

Front. Med. 8:617659.

doi: 10.3389/fmed.2021.617659
Traditional Chinese medicine (TCM) has played a significant role in the treatment of coronavirus disease 2019 (COVID-19) in Wuhan City. During the epidemic, Academician Tong Xiaolin suggested a close association of COVID-19 with cold-dampness, an etiological factor in TCM, by summarizing the characteristics of the COVID-19 patients in Wuhan. and the theory of Cold-dampness Plague was proposed. Based on the Cold-dampness Plague theory, a series of TCM drugs, such as Huoxiang Zhengqi Dropping Pills, Lianhua Qingwen Granules Hanshiyi Formula, and Tongzhi Granule were developed for the different stages, namely mild, moderate, severe, recovery, of the COVID-19. In addition, clinical evidences were obtained through randomized clinical trials or retrospective cohort studies. The Anti-SARS-CoV-2 mechanism of the TCM prescriptions were then summarized from the four aspects: targeting the ACE2 and 3CLPro, targeting cytokines, targeting acute immune responses to SARS-CoV-2, and targeting pulmonary fibrosis. Despite the clinical efficacy and therapeutic pharmacology speculation, more studies such as large-scale randomized clinical trials, cell and animal experiments are needed to further verify the theory of the Cold-dampness Plague in COVID-19 patients.

Keywords: COVID-19, cold-dampness, cold-dampness plague theory, traditional Chinese medicine, infectious disease

\section{INTRODUCTION}

In December 2019, coronavirus disease 2019 (COVID-19), which first broke out in Wuhan City, the capital of Hubei province in China, was identified as being caused by a novel coronavirus named severe acute respiratory syndrome coronavirus 2 (SARS-CoV-2) $(1,2)$. The disease was declared a pandemic by the World Health Organization (WHO), when it rapidly spread across China and rapidly reached other Asian regions, the USA, and some European countries (3-5). Fever, cough, myalgia, or fatigue were the common clinical manifestations in COVID-19 patients, dyspnea usually occurred in severe cases, and was life-threatening (6). Up to 19 September, 2020, $30,369,778$ individuals were infected by COVID-19 globally, including 948,795 death cases (7).

It is worthy of note that in this battle, traditional Chinese medicine (TCM) played a significant role in the prevention, treatment and rehabilitation of COVID-19 in China (8). TCM therapy plan was an indispensable part of the Diagnosis and Treatment Guideline for COVID-19 (3rd-8th edition) released by the National Health Commission of the People's Republic of China (9). 
According to the statistics, as of March 6, 2020, TCM therapy was being administered in $92.36 \%$ of COVID-19 patients in China (10). In contrast to Western medicine, TCM, as one of the primary alternative and complementary medicine, has its own unique theoretical system and methods of understanding human physiology and pathology. Over thousands of years of its clinical use, TCM has accumulated rich experience in the face of more than 300 documented plagues in Chinese history (11).

Considering the symptom observed in COVID-19 patients and environmental and climatic conditions in Wuhan during the epidemic, Academician Tong Xiaolin suggested that the epidemic was closely associated with the pathological stage of cold-dampness, an etiological factor in TCM. Based on the theory of cold-dampness, a series of Chinese medical prescriptions and treatment plans have been developed for COVID-19 patients (Table 1). At the same time, there have been reports that TCM therapy can strengthen immunity, exert anti-inflammatory activity, and promote the elimination of virus from the body, to achieve recovery and prevent complications in COVID-19 patients $(16,17)$. In this review, to fully understand the role of TCM in the prevention and treatment of the epidemic, from the perspective of cold-dampness, we summarize the research regarding its theory, treatments, clinical evidence, and mechanisms for COVID-19 in Wuhan.

\section{TCM THEORY OF COVID-19 FROM THE PERSPECTIVE OF COLD-DAMPNESS}

Based on TCM theory, Tong proposed the role of cold-dampness in the pathogenesis of COVID-19. Unlike Western medicine, TCM often considers the pathogenesis of the disease from a holistic perspective, which includes the disease itself, the environment state without, and the body state within. There is accumulating evidence, from all three aspects, that supports the theory of cold-dampness in COVID-19. Etiological studies have shown that an increase in temperature can accelerate the inactivation of SARS-CoV-2. An increment in temperature, from 24 to $35^{\circ} \mathrm{C}$, resulted in faster virus decay and shorter halflife at relative humidity $(18,19)$. An increase in atmospheric temperature dampened the transmission of the virus, whereas a decrease resulted in new cases of COVID-19; a peak, in the growth of SARS-CoV-2, was observed in the cold season (20). In addition, isolation of SARS-CoV-2 on conditioned frozen food has been suggested as indication of its role as possible source of COVID-19 in one report (21). Under refrigerated (at $4^{\circ} \mathrm{C}$ ) and freezing conditions (from $-10^{\circ} \mathrm{C}$ to $-80^{\circ} \mathrm{C}$ ), SARSCoV-2 remained highly stable on frozen food for 14-21 days, thereby indicating the cold nature of the epidemic (22). Although some researchers are of the opinion that the relative humidity is negatively related to the spread of COVID-19 (23), based on the evidence regarding environmental factors and human body state, we believe that the epidemic has damp characteristics.

As for the environmental state, according to local meteorological data, the precipitation in Wuhan, in January 2020, was 4.6 times the average precipitation observed in the same period during the last 20 years. In a study, that investigated the meteorological factors of the COVID-19, $1 \%$ increase in precipitation led to $0.07 \%$ of decline in recovery cases and 1 and $0.86 \%$ increase in confirmed cases and deaths, respectively (24). In addition, an increase in humidity in the air, during the winter season, can reduce host innate immune response and enhance microbial growth in a closed environment, which can easily worsen the underlying health conditions (especially respiratory illnesses) (25).

According to the theory of Cold-dampness Plague, the COVID-19 comprises of following four stages: (a) mild status in the early stage, (b) moderate status in the middle stage, (c) severe and critical status in the late stage, and (d) rehabilitation status in the recovery stage (26). In the early stage of the disease, usually no manifestations of pneumonia are present on medical imaging, and the cold-dampness constraint in the lung is the major pathological factor. In this stage, the patients present with no or mild clinical symptoms such as fever, aversion to cold, fatigue, sometimes accompanied by muscular weakness, anorexia, diarrhea, etc. In the middle stage of the disease, imaging findings are suggestive of pneumonia, and the colddampness obstructing the lung is the primary pathological factor, and patients usually manifest fever, cough, asthma, abdominal distension, and constipation. In the late stage, due to the colddampness pathogen attacking the internal viscera and a general deficiency of $q i$, acute respiratory distress, including respiratory failure, accompanied with other organ failure appears; an obvious progression of $>50 \%$ in the lesion, within $24-48 \mathrm{~h}$, is observed on chest imagings (14). The symptoms of dyspnea, coma, dysphoria, sweating and cold limbs usually manifest in severe and critical cases. In the recovery stage, although consecutively negative RT-PCR tests and improvement in chest radiography are obtained, the patients usually have mild clinical symptoms such as shortness of breath, fatigue and poor appetite. This phenonmenon is mainly due to remaining cold-dampness pathogen in the body (27). Despite the fact that symptoms at different stages are varied, the cold-damp plague attacking the respiratory system and subsequently involving other organs, as the diasease progresses, is the core pathogenesis of COVID-19. According to TCM theory, the treatment is aimed to dispel cold and remove dampness, thereby regulating the whole body state, promoting the excretion of the virus, and restoring the immunity.

\section{THE CLINICAL EVIDENCES OF COLD-DAMP NATURE OF COVID-19}

\section{Treatment of Suspected and Diagnosed Cases of COVID-19 (12)}

For suspected and mild cases of COVID-19, TCM prescriptions, Huoxiang Zhengqi Dropping Pills (HZDP) and Lianhua Qingwen Granules (LQG) were prescribed from the perspective of cold-dampness nature in the early and middle stage of the cold-damp plague. Under the guideline of the cold-dampness TCM theory, HZDP was administered for the pathogenesis of dampness and LQG for the cold; thus, the combination of HZDP and LQG was recommended to dispel cold-dampness pathogens from the body. Both two TCM prescriptions have been 
TABLE 1 | Summary of the included studies.

\begin{tabular}{|c|c|c|c|c|c|}
\hline Study ID & Sample size & Intervention method & $\begin{array}{l}\text { Duration of } \\
\text { interventions }\end{array}$ & Complications & Primary outcome \\
\hline Xiao et al. (12) & $\begin{array}{l}n=182 \text { (LQG group } n= \\
58, \text { LQG+HZDP group } n= \\
\text { 61, WM group } n=63 \text { ) } \\
\text { Male: LQG group } 60.3 \% \text {, } \\
\text { LQG+HZDP group } 54.1 \% \text {, } \\
\text { WM group 55.6\% } \\
\text { Mean age (SD): LQG group } \\
\text { 52.86 } \pm 13.95, \text { LQG+HZDP } \\
\text { group } 56.07 \pm 12.10, \text { WM } \\
\text { group } 53.90 \pm 13.92\end{array}$ & $\begin{array}{l}\text { RCT } \\
\text { HZDP (Pogostemon cablin (Blanco) Benth, } \\
\text { Atractylodes lancea (Thunb.) DC., } \\
\text { Magnolia officinalis Cortex, Angelicae } \\
\text { dahurica Radix, Poria cocos (Schw.) Wolf, } \\
\text { Areca catechu L., Pinellia ternate (Thunb.) } \\
\text { Breit., Glycyrrhizae Radix et Rhizoma, } \\
\text { Perilla frutescens, and Citrus reticulata), } \\
\text { 2.6 g, twice a day. } \\
\text { LQG (Forsythia suspensa (Thunb.) Vahl, } \\
\text { Ephedra sinica Stapf, Lonicera japonica } \\
\text { Thunb., Isatis indigotica Fortune, Mentha } \\
\text { haplocalyx Briq., Dryopteris crassirhizoma } \\
\text { Nakai, Rhodiola rosea L., Gypsum } \\
\text { Fibrosum, Pogostemon cablin (Blanco) } \\
\text { Benth., Rheum palmatum L., Houttuynia } \\
\text { cordata Thunb., and Glycyrrhiza uralensis } \\
\text { Fisch. Armeniaca sibirica (L.) Lam), 6 g, } \\
\text { three times a day. }\end{array}$ & $\begin{array}{l}\text { LQG group: } 12.47 \pm \\
\text { 3.16 days } \mathrm{LQG}+\mathrm{HZDP} \\
\text { group: } 12.79 \pm 2.94 \\
\text { days } \\
\text { WM group: } 13.14 \pm \\
2.54 \text { days }\end{array}$ & $\begin{array}{l}\text { Bronchial asthma, chronic } \\
\text { obstructive pulmonary } \\
\text { disease, coronary artery } \\
\text { disease, high blood } \\
\text { pressure, diabetes, } \\
\text { hyperlipidemia, and others. }\end{array}$ & $\begin{array}{l}\text { The proportion of } \\
\text { patients who } \\
\text { progressed to severe } \\
\text { status and clinical } \\
\text { symptoms }\end{array}$ \\
\hline Tian et al. (13) & $\begin{array}{l}\mathrm{n}=721 \\
\text { (treatment arm } n=430 \\
\text { control arm } n=291 \text { ) } \\
\text { Male: } 48.1 \% \\
\text { Mean age (SD): } 48.49 \pm \\
14.362 \\
n=721 \text { (treatment arm } n= \\
\text { 430, control arm } n=291 \text { ) } \\
\text { Male: } 48.1 \% \text { Mean age } \\
\text { (SD): } 48.49 \pm 14.362 \\
\end{array}$ & $\begin{array}{l}\text { Retrospective cohort study } \\
\text { HSYF (Ephedrae Herba, Gypsum } \\
\text { fibrosum, Armeniacae Semen, } \\
\text { Notopterygii Rhizoma seu Radix, } \\
\text { Lepidii/Descurainiae Semen, Cyrtomii } \\
\text { Rhizoma, Pheretima, Cynanchi paniculati } \\
\text { Radix, (Pogostemonis Herba, Eupatorii } \\
\text { Herba, Atractylodis Rhizoma, Poria, } \\
\text { Atractylodis macrocephalae Rhizoma, } \\
\text { Crataegi Fructus, Massa medicate } \\
\text { fermentata, Hordei Fructus germinates, } \\
\text { Magnoliae officinalis Cortex, Arecae } \\
\text { Semen, Tsaoko Fructus and Zingiberis } \\
\text { Rhizoma recens) including decoction, } \\
\text { granules, etc. }\end{array}$ & $\begin{array}{l}\text { At least } 2 \text { days. If there } \\
\text { is no adverse effect or } \\
\text { disease progression, } \\
\text { HSYF can be taken } \\
\text { continuously until } \\
\text { recovery. }\end{array}$ & $\begin{array}{l}\text { Hypertension (16.9\%), } \\
\text { coronary heart disease } \\
\text { (4.6\%), diabetes }(7.1 \%) \text {, } \\
\text { bronchial asthma (3.3\%), } \\
\text { chronic obstructive } \\
\text { pulmonary disease (1.2\%), } \\
\text { hyperlipidemia (6.7\%), fatty } \\
\text { liver (7.9\%), gallbladder } \\
\text { disease (2.4\%), thyroid } \\
\text { disease (2.1\%), stroke } \\
\text { (0.3\%), chronic } \\
\text { glomerulonephritis }(0.8 \%), \\
\text { cancer (0.8\%), hepatitis } \\
\text { (2.1\%), tuberculosis }(0.4 \%) \text {, } \\
\text { and other diseases (14.3\%). }\end{array}$ & $\begin{array}{l}\text { The proportion of mild } \\
\text { and moderate } \\
\text { COVID-19 patients } \\
\text { who progressed to a } \\
\text { severe disease status }\end{array}$ \\
\hline Chen et al. (14) & $\begin{array}{l}n=662 \\
\text { (treatment arm } n=484 \\
\text { control arm } \\
n=178) \text { Male: } 44.7 \% \text { Mean } \\
\text { age (SD):60 (47-70) }\end{array}$ & $\begin{array}{l}\text { Retrospective cohort study } \\
\text { HXF (Poria, Astragali Radix, Pogostemon } \\
\text { cablin (Blanco) Benth., Prunus armeniaca } \\
\text { L. var. ansu Maxim., Pinellia ternata } \\
\text { (Thunb.) Breit., Ephedra sinica Stapf, } \\
\text { Cinnamomum cassia Presl, Eupatorium } \\
\text { fortunei Turcz, Codonopsis Radix), } 200 \mathrm{~mL} \\
\text { each time, twice a day in hospital days. }\end{array}$ & NR & $\begin{array}{l}\text { Chronic obstructive lung } \\
\text { disease }(2.9 \%) \text {, } \\
\text { hypertension (31.4\%), } \\
\text { cardiovascular disease } \\
\text { (8.0\%), diabetes (14.2\%), } \\
\text { malignancy (1.8\%), } \\
\text { cerebrovascular disease } \\
\text { (5.7\%), chronic kidney } \\
\text { disease }(0.6 \%), \text { and chronic } \\
\text { liver disease }(1.2 \%) .\end{array}$ & Mortality rate \\
\hline He et al. (15) & $\begin{array}{l}n=420 \\
\text { (treatment arm } n=325, \\
\text { control arm } n=95) \\
\text { Male:49.0\% } \\
\text { Mean age (SD): } 56 \\
(43-63.75)\end{array}$ & $\begin{array}{l}\text { Retrospective observational Study } \\
\text { TZG (Astragali Radix } 15 \mathrm{~g} \text {, Codonopsis } \\
\text { Radix } 15 \mathrm{~g} \text {, Atractylodis Macrocephalae } \\
\text { Rhizoma } 15 \mathrm{~g} \text {, Adenophorae Radix } 15 \mathrm{~g} \text {, } \\
\text { Glehniae Radix } 15 \mathrm{~g} \text {, Ophiopogonis Radix } \\
15 \mathrm{~g} \text {, Citri Reticulatae Pericarpium } 15 \mathrm{~g}, \\
\text { Poria } 15 \mathrm{~g} \text {, Pinelliae Rhizoma Praeparatum } \\
9 \mathrm{~g} \text {, Anemarrhenae Rhizoma } 12 \mathrm{~g} \text {, Salviae } \\
\text { Miltiorrhizae Radix et Rhizoma } 15 \mathrm{~g} \text {, } \\
\text { Fritillariae Thunbergii Bulbus } 15 \mathrm{~g},\end{array}$ & $\begin{array}{l}\text { Median course of } \\
\text { disease was } 40 \text { days }\end{array}$ & $\begin{array}{l}\text { Hypertension (26.4\%), } \\
\text { hyperlipidemia (10.7\%), } \\
\text { diabetes (10.5\%), coronary } \\
\text { heart disease }(5.5 \%) \text {, } \\
\text { hepatopathy }(3.1 \%) \text {, chronic } \\
\text { bronchitis (2.9\%), } \\
\text { hyperuricemia malignant } \\
\text { tumor (1.7\%), chronic } \\
\text { nephritis (1.0\%), and } \\
\text { cerebral apoplexy (1.0\%). }\end{array}$ & $\begin{array}{l}\text { RT-PCR test result of } \\
\text { the observed subjects } \\
\text { at the end of quarantine }\end{array}$ \\
\hline
\end{tabular}

Paeoniae Radix Rubra $15 \mathrm{~g}$, Platycodonis Radix $15 \mathrm{~g}$, Saposhnikoviae Radix $9 \mathrm{~g}$, Glycyrrhizae Radix et Rhizoma $6 \mathrm{~g}$, Fructus Hordei Germinatus $9 \mathrm{~g}$, Crataegi Fructus $9 \mathrm{~g}$, Massa Medicata Fermentata $9 \mathrm{~g}$, Rhizoma Dioscoreae $15 \mathrm{~g}$ ), administered to 1 bag (dissolved in $200 \mathrm{~mL}$ of water at $95^{\circ} \mathrm{C}$ ) per day, twice a day. inuously unti pulmonary disease hyperlipidemia (6.7\%), fatty iver (7.9\%), gallbladder disease $(0.6 \%)$, and chronic liver disease (1.2\%). heart disease $(5.5 \%)$, patopathy (3.1\%), chronic hyperuricemia malignant cerebral apoplexy (1.0\%). 
widely applied in the infectious diseases such as Severe Acute Respiratory Syndrome (SARS) and influenza in China before (28-30). In our randomized controlled trial (RCT) of HZDP and LQG, conducted in Wuhan, 188 diagnosed and 95 suspected COVID-19 patients were enrolled. The patients were randomly divided into three group, namely the LQG, a combination of HZDP and LQG and western medicine group, in a ratio of 1:1:1. Among the three groups, the utilization rate of anti-infective drugs (including oseltamivir, arbidol and macrolide antibiotics) was significantly higher in the western medicine group $(P<$ 0.05). After 14 days of treatment, among the 182 diagnosed COVID-19 patients who completed the study, the proportion of patients who progressed to severe status was lowest in the HZDP+LQG group (1.6\%), when compared to the LQG group $(8.6 \%)$ and the western medicine group (11.1\%). With respect to the symptom improvement, in all three intervention groups, fever and diarrhea was alleviated, whereas the HZDP+LQG group had obvious advantages in relieving nausea, vomiting, and limb soreness. Above all, the results of our study suggested that the combination of HZDP and LQG developed from the colddampness perspective has potential advantages in the treatment of suspected and diagnosed cases of COVID-19.

\section{Treatment of Mild and Moderate Cases of COVID-19 (13)}

Under the guidance of cold-damp plague theory, a TCM prescription. Hanshiyi Formula (HSYF), was formulated for mild and moderate COVID-19 patients; HSYF was composed of herbs meant to reduce lung inflammation and expel cold-dampness from the body. In our cohort study, 721 patients with mild and moderate COVID-19, from 17 quarantine stations in Wuchang District of Wuhan, were enrolled. Of total, 430 patients received HSYF (exposed group) and 291 did not receive HSYF (control group). In the exposed group, none of the patients (0.0\%) turned severe; however, 19 patients $(6.5 \%, P<0.001)$ in the control group transitioned to severe status. The difference between the two groups in terms of progression to severe disease (exposed group-control group) was $-6.5 \%$ [95\% CI: $(-8.87 \%,-4.13 \%)]$. Considering the difference in sample size between the two groups and the imbalance of confounding factors, a univariate logistic regression analysis was used. After a 1:1 ratio of propensity score matching (PSM), the sample size of HSYF users and non-users were both 148, and it's found that no HSYF users progressed to severe status of COVID-19, whereas $4.7 \%$ non-users turned to severe status, the difference between the two groups was -4.7 $\%$ [95\% CI: $(-8.2 \%,-1.2 \%)]$. Comparing with the $14 \%$ of cases which can develop into severe status according to the report of the WHO-China joint mission (31), the result of the study showed that HSYF was effective in reducing the progression of mild and moderate COVID-19 patients to severe status. However, further larger scale of clinical studies are required to further verify the result.

\section{Treatment on the Severe and Critical Cases of COVID-19 (14)}

According to the TCM theory of COVID-19 from the colddampness perspective, severe and critical COVID-19 patients developed respiratory system failure, often accompanied with other organs failure resulting from the cold-dampness pathogen in the respiratory tract attacking the internal viscera. Based on the TCM theory and the disease prognosis, Hexin Formula (HXF) was developed to halt progression of the disease and to treat the severe and critical COVID-19 patients. Although currently there is no appropriate treatment plan for severe and critical COVID-19 patients, there is evidence supporting TCM, as besides providing supportive treatment, it can aid in the treatment of severe COVID-19 (32). In our retrospective cohort study of 662 patients in Wuhan with severe and critical COVID19 , the mortality risk of TCM users was reduced by $82.2 \%$ (odds ratio $0.178,95 \%$ CI $0.076-0.418 ; P<0.001$ ), when compared to the non-users, suggesting that HXF guided by the TCM theory of cold-damp plague may reduce the mortality and can be used as an alternative treatment option besides conventional antiviral and supportive treatment.

\section{Treatment of COVID-19 Patients in the Recovery Stage With Positive RT-PCR Test Results (15)}

Among recovered COVID-19 patients, some have recurrent transcriptase-polymerase chain reaction (RT-PCR) test results. This phenomenon of recurrent positive RT-PCR test results further adds to the difficulty in controlling COVID-19, not only in China but also around the world. At present, there is no specific treatment for these individuals, as they usually manifest as no or mild symptoms, and their infectivity is also uncertain. According to TCM theory, this is mainly because of lack of healthy visceral $q i$, and remaining cold-dampness pathogen in the body. Considering the role of cold-damp plague in the recovery stage, a universal TCM prescription, Tongzhi Granule (TZG), was developed, that focused on nourishing healthy $q i$ and expelling residual cold-damp pathogen from the body. In our retrospective cohort study of 420 recovered COVID-19 patients with positive RT-PCR results, the recurrence rate of positive RTPCR test results was lower in the TZG group, when compared to a control group (2.8\% [9/325] vs. 15.8\% [15/95]). Thus, indicating that TCM intervention using TZG guided by the cold-damp plague theory may play a positive role in reducing the RT-PCR test results in the patients recovered from COVID-19.

\section{ANTI-SARS-CoV-2 MECHANISM AND THERAPEUTIC PHARMACOLOGY}

SARS-CoV-2 (2019-nCoV) is a member of the family coronaviridae and genus betacoronavirus, and is closely related to two bat-derived SARS-like coronaviruses (bat-SL-CoVZC45 and bat-SL-CoVZC21) (33). Although CoVs have species diversity, they share key genomic elements. Sequence analysis showed that the 2019-nCoV has structural features typical of coronavirus genome (34). Typical CoV genome and subgenome contain six open reading frames (ORFs), which encode 16 non-structural proteins (NSP 1-16), except for $\gamma$ coronavirus, which lacks NSP 1 . There is a -1 frameshift between ORF1a and ORF1b; 5' ORF1 a/b encodes the polypeptides ppla and pplab. These polypeptides are processed into 16 NSPs by virus-encoded 
enzymes, such as 3C-like protease (3CLPro), master protease (mPro), and one or two papain like protease (PLpro) $(35,36)$.

RNA-dependent RNA polymerase RdRp and ExoN enzymes, involved in virus transcription and replication (37), are potential broad-spectrum anti-CoV targets (38). Angiotensinconverting enzyme two (ACE2) is a functional receptor for SARS-Co-2. Therefore, much of the research on the anti$\mathrm{CoV}$ mechanism is focused on 3CLPro, PLpro, ACE2, RdRp and proofreading ExoN. In addition, the cytokine storms and acute immune responses are also important targets. It is widely known that the underlying mechanism in herbal medicines are "multi-component, multi-target, and multi-pathway" (39-41). Traditional Chinese medicine (TCM) plays a vital role and provides unique advantages in the management of COVID19. The possible anti-SARS-CoV-2 mechanisms of the TCM prescriptions, including HZDP, LQG, HSYF, HXF and TZG are shown in Tables 2-6, respectively.

\section{Targeting the ACE2 and 3CLPro}

HSYF is recommended as the first-line of treatment for COVID19. Although due to time limitations, there have been only a few in vivo and in vitro experiments related to COVID19, its efficacy in the clinical settings has been confirmed. Network pharmacology, a branch of pharmacology that uses network methods to analyze the synergistic relationship between drugs and diseases, and targets via "multi-component, multitarget, multi-pathway," can help build a multi-dimensional network model of "drug-component-target-disease" to disclose the molecular mechanisms of multicomponent therapies, such as TCM $(88,89)$. HSYF was used to treat "cold-dampness stagnation in the lung" in COVID-19. Network enrichment analysis showed that HSYF components could to interleukin (IL)-6 and ACE2 (90). Since IL6 plays a central role in the acute inflammatory response, its potential inhibition could significantly improve prognosis in COVID-19 patients (91). SARS-CoV-2, binds to ACE2 in the human body through its expressed S-protein, facilitating its entry into host cells $(92,93)$. Blocking S-protein-binding to ACE2 may interfere with SARSCoV-2 entry.

According to the network analysis, there are five ingredients (glycyrrhetinic acid, stigmasterol, indigo, $\beta$-sitosterol, and luteolin) in LQG that can act on ACE2. Molecular docking showed that these active ingredients could bind to ACE2, and their binding ability was higher than that of lopinavir, ritonavir, and ribavirin. 3CLpro is highly conserved in its genes and produces RNA-dependent RNA polymerase (RdRp) during the replication process of the coronavirus (94). Findings from gene network enrichment analysis showed that LQG could inhibit SARS-CoV 3C-like protease (3CLpro), thereby blocking the production of 16 non-structural proteins (95). Moreover, previous pharmacodynamics studies have demonstrated that LQG could significantly inhibit the activity of SARS-CoV in vitro culture and reduce the viral loads in the cytoplasm and cellular membrane (17).

Investigations of the effect of the HZDP on SARS-CoV-2 have yielded a consistent picture. Molecular docking showed that the five components of HXZQ (Elicorice glycoside E, naringenin, robinin, kaempferol, [(2R)-7-hydroxy-2- (4-hydroxyphenyl) chroman-4-one]), binds to 3CLpro, with an ability better than Remdesivir (96). These compounds contain flavonoid cores, and previous studies have demonstrated that flavonoids have a wide range of antibacterial and antiviral effects (97, 98). The schematic diagram illustrating proposed activity model of Herbal medicine in targeting 3C-like Proteinase (3CLPro) and Angiotensin converting enzyme two (ACE2) are presented in Figure 1.

\section{Targeting Cytokine}

Cytokine storm syndrome (CSS) is a systemic inflammatory response that can be triggered by multiple factors such as infections and certain drugs (99). It is characterized by a sharp increase in the levels of pro-inflammatory cytokines, such as tumor necrosis factor (TNF)- $\alpha$, IL-1, IL-6, IL-12, Interferon (IFN)- $\alpha$, IFN- $\beta$, IFN- $\gamma$, monocyte chemoattractant protein1 (MCP-1), and IL-8 (100). Cytokine storm syndromes are devastating clinical conditions that result from dysregulated immune responses to inflammatory and infectious triggers (101). These cytokines attack the immune system, causing acute respiratory distress syndrome and multiple organ failure (102). In the previous studies, cytokine storms have occurred during the infection process of SARS, Middle East Respiratory Syndrome and Ebola virus (103). Positive control of CSS is of great importance to the treatment, management, and prognosis of CSS.

A network pharmacology study showed that HSYF could play a role in immune regulation through proinflammatory and antiinflammatory cytokines and exerts antiviral effects by regulating the hub targets IL6, TNF, IL10, mitogen activated protein kinase(MAPK)-8, MAPK3, chemokine (CXCL)-8, caspase (CASP)-3, Prostaglandin-Endoperoxide Synthase (PTGS)-2, tumor protein $\mathrm{p}$ (TP)-53, and MAPK1 (90). IL6 and TNF play key roles in the cytokine storm. The most notable factor was IL6, which plays a key role in the cytokine storm, and is used as a clinical early warning index in the diagnosis and treatment of COVID-19. IL6 plays a central role in the acute inflammatory response, and a long duration of its release can also be used to assess the severity of infection and judge prognosis. Dynamic observation of IL-6 levels can assist in understanding the progression of infectious diseases and the response to treatment. In another network pharmacology, LQG could control inflammatory responses by regulating IL10, CD40 ligand, TNF, ACE2, IL-6, IFNA1, IL2 and $\operatorname{ACE}(94,95,104)$. Moreover, LQG could block the activation of the MAPK signaling pathway, thereby inhibiting the release of inflammatory cytokines, and consequently reducing inflammation in tissues (105). Several studies have indicated that LQG can not only suppress the release of TNF- $\alpha$, IL6, MCP1 and CXCL-10 (106), but also reduce the expression of IL$1 \beta$, IL-2, IL-4 and IL-13 (107). Thus, suggesting that LQG can inhibit cytokine storm and relieve lung injury associated with inflammatory cell infiltration.

In addition, a retrospective cohort study showed that herbal medicine, (Ephedra sinica Stapf, Cinnamomum cassia Presl, Prunus armeniaca L. var. ansu Maxim., Poria, Pinellia ternata (Thunb.) Breit., Pogostemon cablin (Blanco) Benth., Eupatorium fortunei Turcz., Astragali Radix, Codonopsis Radix), could 
TABLE 2 | Herbal medicine of HZDP used in the treatment of COVID-19 according to their effects, targets and mechanisms of action.

\begin{tabular}{|c|c|c|c|c|c|}
\hline $\begin{array}{l}\text { Herbal } \\
\text { formula }\end{array}$ & $\begin{array}{l}\text { Herbal medicine } \\
\text { (components) }\end{array}$ & Effects & Targets & Mechanism of action & Reference \\
\hline \multirow[t]{13}{*}{ HZDP } & $\begin{array}{l}\text { Pogostemon cablin (Blanco) } \\
\text { Benth (Patchouli alcohol) }\end{array}$ & $\begin{array}{l}\text { Anti-H1N1 Influenza } \\
\text { Virus }\end{array}$ & RLH pathway & $\begin{array}{l}\text { Inhibited the expression of cytokines and the mRNA } \\
\text { of RLH pathway. }\end{array}$ & $(42)$ \\
\hline & $\begin{array}{l}\text { Atractylodes lancea (Thunb.) } \\
\text { DC. (Atractylodes lactone } \\
\text { land III) }\end{array}$ & $\begin{array}{l}\text { Anti-inflammatory } \\
\text { activity }\end{array}$ & TNF- $\alpha, \mathrm{IL}-1 \beta$ and IL-6 & $\begin{array}{l}\text { Promoted the expression of cytokines in } \\
\text { inflammatory macrophages. }\end{array}$ & $(43)$ \\
\hline & $\begin{array}{l}\text { Magnolia officinalis Cortex } \\
\text { (Honokiol) }\end{array}$ & Resisted lung injury & $\begin{array}{l}\text { TLR4-NF-кB pathway, } \\
\text { Th17/Treg cells }\end{array}$ & $\begin{array}{l}\text { Inhibited TLR4-NF-кB pathway-mediated } \\
\text { inflammatory response or regulated the balance of } \\
\text { Th17/Treg cells. }\end{array}$ & $(44)$ \\
\hline & $\begin{array}{l}\text { Pinellia ternate (Thunb.) } \\
\text { Breit. } \\
\text { (Alkaloid) }\end{array}$ & $\begin{array}{l}\text { Had protective effect } \\
\text { on pulmonary epithelial } \\
\text { cells }\end{array}$ & $\begin{array}{l}\text { NO, TNF- } \alpha, \text { IL- } 8 \text { and } \\
\text { ICAM-1 }\end{array}$ & $\begin{array}{l}\text { Inhibited the release of NO, TNF- } \alpha \text {. Inhibited the } \\
\text { expression of IL-8 and ICAM- } 1 \text {. }\end{array}$ & $(45)$ \\
\hline & $\begin{array}{l}\text { Perilla frutescens } \\
\text { (P. frutescens extract) }\end{array}$ & $\begin{array}{l}\text { Regulated the } \\
\text { inflammatory activities }\end{array}$ & $\begin{array}{l}\text { SFKs (Src and Lyn) and } \\
\text { mobilization of } \\
\text { intracellular } \mathrm{Ca}+\end{array}$ & $\begin{array}{l}\text { Inhibited fMLF-induced phosphorylation of } \\
\text { the Src family kinases (SFKs), Src (Tyr416) and Lyn } \\
\text { (Tyr396). Reduced their enzymatic activities. } \\
\text { Decreased intracellular Ca2+ levels ([Ca2+] i). }\end{array}$ & $(46)$ \\
\hline & Angelicae dahurica Radix & $\begin{array}{l}\text { Regulated the } \\
\text { inflammatory activities }\end{array}$ & $\begin{array}{l}\mathrm{IL}-1 \beta, \mathrm{IL}-6, \mathrm{IL}-8, \mathrm{IFN}-\gamma \\
\text { NF-kB, COX-2 and } \\
\text { iNOS }\end{array}$ & $\begin{array}{l}\text { Reduced the expressions of IL- } 1 \beta, \mathrm{IL}-6, \mathrm{IL}-8, \mathrm{IFN}-\gamma \text {, } \\
\mathrm{NF}-\mathrm{kB}, \mathrm{COX}-2 \text { and iNOS protein levels. }\end{array}$ & $(47)$ \\
\hline & $\begin{array}{l}\text { Citrus reticulata } \\
\text { (Citrus reticulata essential } \\
\text { oil) }\end{array}$ & $\begin{array}{l}\text { Had preventive effects } \\
\text { on pulmonary fibrosis in } \\
\text { rats }\end{array}$ & $\begin{array}{l}\text { CTGFprotein, mRNA, } \\
\text { Collagendeposition. }\end{array}$ & $\begin{array}{l}\text { Adjusted the unbalance of oxidation and } \\
\text { antioxidation. } \\
\text { Down-regulated CTGF protein and mRNA } \\
\text { expressions. } \\
\text { Reduced collagendeposition. }\end{array}$ & $(48)$ \\
\hline & $\begin{array}{l}\text { Poria cocos (Schw.) Wolf } \\
\text { (Polysaccharide) }\end{array}$ & $\begin{array}{l}\text { Enhanced humoral and } \\
\text { cellular immunity }\end{array}$ & $\begin{array}{l}\text { Splenocytes,IL-12p70 } \\
\text { and TNF- } \alpha\end{array}$ & $\begin{array}{l}\text { Improved proliferation of splenocytes. Stimulated } \\
\text { IL-12p70 } \\
\text { and TNF- } \alpha \text { productions in dendritic cells and } \\
\text { macrophages. }\end{array}$ & $(49)$ \\
\hline & $\begin{array}{l}\text { Platycodonis Radix } \\
\text { (Total Saponins) }\end{array}$ & $\begin{array}{l}\text { Improved inflammatory } \\
\text { reactions }\end{array}$ & $\begin{array}{l}\text { IRG-1, IL-6, IL-1 } 1 \beta \\
\text { TNF- } \alpha \text { and ROS }\end{array}$ & $\begin{array}{l}\text { Inhibited the expression of IRG-1. Reduced } \\
\text { contents of IL-6, IL-1 } \beta \text {, TNF- } \alpha \text { and ROS. }\end{array}$ & $(50)$ \\
\hline & $\begin{array}{l}\text { Glycyrrhizae Radix et } \\
\text { Rhizoma } \\
\text { (Glycyrrhizin) }\end{array}$ & $\begin{array}{l}\text { reduced the severity of } \\
\text { an infection with } \\
\text { COVID-19 }\end{array}$ & ACE2 & $\begin{array}{l}\text { Reduced the expression of ACE2 in the } \\
\text { Lung. }\end{array}$ & $(51,52)$ \\
\hline & $\begin{array}{l}\text { Jujubae Fructus } \\
\text { (Polysaccharides) }\end{array}$ & $\begin{array}{l}\text { Had anti-inflammatory } \\
\text { activity }\end{array}$ & IL-6, TNF- $\alpha$ & $\begin{array}{l}\text { Suppressed proinflammatory cytokines, such as } \\
\text { IL- } 6 \text { and TNF- } \alpha \text {. }\end{array}$ & (53) \\
\hline & $\begin{array}{l}\text { Areca catechu L. } \\
\text { (Extract of Areca catechu) }\end{array}$ & $\begin{array}{l}\text { Had anti-inflammatory } \\
\text { activity }\end{array}$ & None & None & $(54)$ \\
\hline & $\begin{array}{l}\text { Zingiberis Rhizoma Recens } \\
\text { (Aqueous extract) }\end{array}$ & $\begin{array}{l}\text { Had anti-inflammatory } \\
\text { activity }\end{array}$ & $\begin{array}{l}\text { macrophage, } \\
\text { neutrophils, monocyte } \\
\text { and leukocyte }\end{array}$ & $\begin{array}{l}\text { Inhibited macrophage and neutrophils activation as } \\
\text { well as negatively affected monocyte and leukocyte } \\
\text { migration. }\end{array}$ & $(55)$ \\
\hline
\end{tabular}

reduce the risk of morbidity in severe and critical COVID19 (14). Although there is no direct evidence available for the effect of these herbal medicines on COVID-19, some indirect evidence supports the possibility of an association. In an in vivo experiment, Ephedra sinica Stapf effectively reduced the secretion of Th2 cytokines (IL-4, IL-5, IL-13) in mouse lung tissue and alveolar lavage fluid (108). In another in vitro anti-inflammatory experiment, Ephedra sinica Stapf inhibited the expression of IL-1 $\beta$, IL- 6 , TNF- $\alpha$, inducible nitric oxide synthase (iNOS), and macrophages (109). Gypsum fibrosum reduced the serum levels of TNF- $\alpha$ and IL- 6 , and IL-1 $\beta$, TNF$\alpha$, and IL- 6 in lung tissues in mice with systemic inflammatory response syndrome induced by lipopolysaccharide (110). Prunus armeniaca L. var. ansu Maxim. reduced the serum levels of TNF$\alpha$ and soluble intercellular adhesion molecule-1 in rats with adjuvant arthritis, thereby slowing the development of tissue inflammation (111). The abovementioned evidence supports the role of these herbal medicines in targeting cytokines.

The schematic diagram illustrating proposed activity model of Herbal medicine in targeting cytokine is presented in Figure 2.

\section{Targeting Acute Immune Responses to SARS-CoV-2}

SARS-CoV-2 infects human lung epithelium through the receptor ACE2. The viral RNA activates endosomal and cytoplasmic sensors, Toll-like receptors (TLR)-3/7 and mitochondrial antiviral signaling protein, respectively. These receptors activate IFN regulatory factor (IRF) and Nuclear factor kappa B (NF-kB) to induce inflammatory cytokines, including interferon (IFN). Dendritic cell (DC) sample antigens 
TABLE 3 | Herbal medicine of LQG used in the treatment of COVID-19 according to their effects, targets and mechanisms of action.

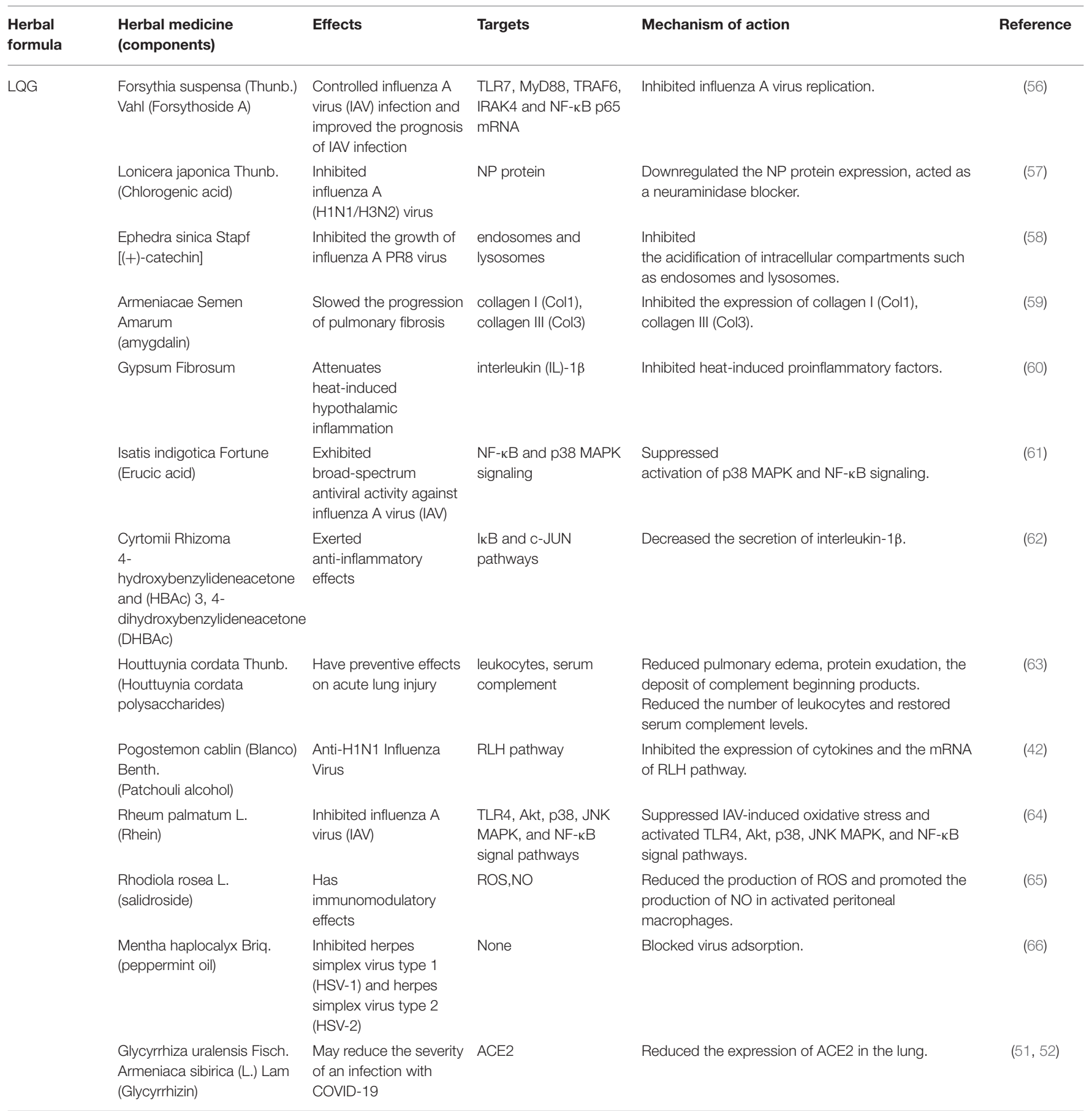

migrate to lymphoid organs to trigger adaptive immunity. After recognizing antigens on DC or infected cells, CD8 T cells induce apoptosis (112-117). NF- $\kappa$ B plays a critical role in inflammation and the development of innate and adaptive immunity (118).

According to a network pharmacology study, LQG was involved in pathways related to innate immunity, including TLR, $\mathrm{NF}-\kappa \mathrm{B}$, and type I interferon and such as Janus kinase/signal transducer and activator of transcription, MAPK1, CXCL2 (94, 95). Type I IFN is an early product of the innate immune response to viral infection (114). Activated NF- $\kappa \mathrm{B}$ induces the expression of type I IFN, which triggers the migration of DC sample antigens to lymphoid organs (118). Forsythiaside, the active ingredient of LQG, can positively regulate the expression of interferon- $\alpha$ (IFN$\alpha$ ), hence exerting immune regulatory and antiviral effects (119). The schematic diagram illustrating proposed activity model of 
TABLE 4 | Herbal medicine of HSYF used in the treatment of COVID-19 according to their effects, targets and mechanisms of action.

\begin{tabular}{|c|c|c|c|c|c|}
\hline $\begin{array}{l}\text { Herbal } \\
\text { formula }\end{array}$ & $\begin{array}{l}\text { Herbal medicine } \\
\text { (components) }\end{array}$ & Effects & Targets & Mechanism of action & Reference \\
\hline \multirow[t]{20}{*}{ HSYF } & $\begin{array}{l}\text { Ephedrae Herba } \\
{[(+) \text {-catechin }]}\end{array}$ & $\begin{array}{l}\text { Inhibited the growth of } \\
\text { influenza A PR8 virus }\end{array}$ & endosomes, lysosomes & $\begin{array}{l}\text { Ilnhibited the acidification of intracellular } \\
\text { compartments such as endosomes and lysosomes. }\end{array}$ & $(58)$ \\
\hline & Gypsum fibrosum & $\begin{array}{l}\text { Attenuates } \\
\text { heat-induced } \\
\text { hypothalamic } \\
\text { inflammation }\end{array}$ & interleukin (IL)-1 $\beta$ & Inhibited heat-induced proinflammatory factors. & $(60)$ \\
\hline & $\begin{array}{l}\text { Armeniacae Semen } \\
\text { (amygdalin) }\end{array}$ & $\begin{array}{l}\text { Slowed the progression } \\
\text { of pulmonary fibrosis }\end{array}$ & $\begin{array}{l}\text { collagen I (Col1), } \\
\text { collagen III (Col3) }\end{array}$ & $\begin{array}{l}\text { Inhibited the expression of collagen I (Col1), } \\
\text { collagen III (Col3). }\end{array}$ & (59) \\
\hline & $\begin{array}{l}\text { Notopterygii Rhizoma seu } \\
\text { Radix } \\
\text { (extract of notopterygium) }\end{array}$ & $\begin{array}{l}\text { Inhibited the } \\
\text { development of asthma }\end{array}$ & $\begin{array}{l}\text { Th1 / Th2 cells, p38 } \\
\text { signaling pathway }\end{array}$ & $\begin{array}{l}\text { Changed Th1 / Th2 cells balance. } \\
\text { Inhibited p38 signaling pathway. }\end{array}$ & $(67)$ \\
\hline & Lepidii/Descurainiae Semen & $\begin{array}{l}\text { Alleviated eosinophilic } \\
\text { inflammation }\end{array}$ & Th2 cell & Inhibited T helper 2 (Th2) cell differentiation. & (68) \\
\hline & $\begin{array}{l}\text { Cyrtomii Rhizoma } \\
\text { (4- } \\
\text { hydroxybenzylideneacetone } \\
\text { and (HBAc) 3, 4- } \\
\text { dihydroxybenzylideneacetone } \\
\text { (DHBAc)) }\end{array}$ & $\begin{array}{l}\text { Exerted } \\
\text { anti-inflammatory } \\
\text { effects }\end{array}$ & $\begin{array}{l}\text { ІкB and c-JUN } \\
\text { pathways }\end{array}$ & Decreased the secretion of interleukin- $1 \beta$. & $(62)$ \\
\hline & $\begin{array}{l}\text { Pheretima } \\
\text { (Pheretima aspergillum } \\
\text { decoction) }\end{array}$ & $\begin{array}{l}\text { Suppressed } \\
\text { inflammation and } \\
\text { relieved asthma }\end{array}$ & $\begin{array}{l}\text { IL-4, IL-5, IL-13, IgE, } \\
N F-\kappa B \text { signaling }\end{array}$ & $\begin{array}{l}\text { Decreased the mRNA and protein levels of IL-4, IL-5 } \\
\text { and IL-13 and downregulated IgE. } \\
\text { Inhibited the activation of NF- } \mathrm{B} \text { s signaling. }\end{array}$ & (69) \\
\hline & $\begin{array}{l}\text { Cynanchi paniculati Radix } \\
\text { (Cynanchum paniculatum } \\
\text { (Bge.) Kitag extract) }\end{array}$ & $\begin{array}{l}\text { Suppressed bovine } \\
\text { viral diarrhea (BVD) } \\
\text { virus }\end{array}$ & & & $(70)$ \\
\hline & $\begin{array}{l}\text { Pogostemonis Herba } \\
\text { (Patchouli alcohol) }\end{array}$ & $\begin{array}{l}\text { Anti-H1N1 Influenza } \\
\text { Virus }\end{array}$ & RLH pathway & $\begin{array}{l}\text { Inhibited the expression of cytokines and the mRNA } \\
\text { of RLH pathway. }\end{array}$ & $(42)$ \\
\hline & $\begin{array}{l}\text { Eupatorii Herba } \\
\text { (flavonoids) }\end{array}$ & $\begin{array}{l}\text { Have antibacterial } \\
\text { activities }\end{array}$ & $\begin{array}{l}\text { Staphylo tetragenus, } \\
\text { staphyloccocus } \\
\text { aureus, Escherichia coli } \\
\text { and bacillus subtilis }\end{array}$ & None & $(71)$ \\
\hline & $\begin{array}{l}\text { Atractylodis Rhizoma } \\
\text { (Volatile oil) }\end{array}$ & $\begin{array}{l}\text { Has anti-inflammatory } \\
\text { effect }\end{array}$ & PGE2 & $\begin{array}{l}\text { Inhibited prostaglandin (PGE2) generation in the } \\
\text { relevant tissue. }\end{array}$ & $(72)$ \\
\hline & Poria (polysaccharide) & $\begin{array}{l}\text { Enhanced humoral and } \\
\text { cellular immunity }\end{array}$ & $\begin{array}{l}\text { Splenocytes,IL-12p70 } \\
\text { and TNF- } \alpha\end{array}$ & $\begin{array}{l}\text { Improved proliferation of splenocytes. Stimulated } \\
\text { IL-12p70 and TNF- } \alpha \text { productions in dendritic cells } \\
\text { and macrophages }\end{array}$ & (49) \\
\hline & $\begin{array}{l}\text { Atractylodis macrocephalae } \\
\text { Rhizoma } \\
\text { (Atractylodes lactoneland III) }\end{array}$ & $\begin{array}{l}\text { Anti-inflammatory } \\
\text { activity }\end{array}$ & TNF- $\alpha, \mathrm{IL}-1 \beta$ and IL-6 & $\begin{array}{l}\text { Promoted the expression of cytokines in } \\
\text { inflammatory macrophages. }\end{array}$ & $(43)$ \\
\hline & $\begin{array}{l}\text { Crataegi Fructus } \\
\text { (Maslinic acid) }\end{array}$ & $\begin{array}{l}\text { Had anti-inflammatory } \\
\text { properties }\end{array}$ & $\begin{array}{l}\text { hGIIA-sPLA2-induced } \\
\text { THP-1 cell }\end{array}$ & $\begin{array}{l}\text { Inhibited hGIIA-sPLA2-induced THP-1 cell } \\
\text { differentiation and migration. } \\
\text { Binded and inhibited hGIIA-sPLA2 enzymatic } \\
\text { activity. }\end{array}$ & (73) \\
\hline & Massa medicate fermentata & None & None & None & None \\
\hline & $\begin{array}{l}\text { Hordei Fructus germinates } \\
\text { (Glutamine-rich protein, } \\
\text { hemicellulose-rich fiber) }\end{array}$ & $\begin{array}{l}\text { Reduce the epithelial } \\
\text { inflammatory response }\end{array}$ & STAT3, NFkB & $\begin{array}{l}\text { Depressed signal transducer and activator of } \\
\text { transcription } 3 \text { (STAT3) expression and inhibited } \\
\text { nuclear factor kappa B (NFkB) binding activity. }\end{array}$ & $(74)$ \\
\hline & $\begin{array}{l}\text { Magnoliae officinalis Cortex } \\
\text { (Honokiol) }\end{array}$ & Resisted lung injury & $\begin{array}{l}\text { TLR4-NF-кB pathway, } \\
\text { Th17/Treg cells }\end{array}$ & $\begin{array}{l}\text { Inhibited TLR4-NF-кB pathway-mediated } \\
\text { inflammatory. response or regulated the balance of } \\
\text { Th17/Treg cells. }\end{array}$ & $(44)$ \\
\hline & $\begin{array}{l}\text { Arecae Semen } \\
\text { (crude extract of Areca } \\
\text { catechu) }\end{array}$ & $\begin{array}{l}\text { Repressed the PGE } 2 \\
\text { and arachidonic } \\
\text { acid-induced } \\
\text { inflammation }\end{array}$ & None & None & (54) \\
\hline & $\begin{array}{l}\text { Zingiberis Rhizoma recens } \\
\text { (Aqueous extract) }\end{array}$ & $\begin{array}{l}\text { Had anti-inflammatory } \\
\text { activity }\end{array}$ & $\begin{array}{l}\text { macrophage, } \\
\text { neutrophils, monocyte } \\
\text { and leukocyte }\end{array}$ & $\begin{array}{l}\text { Inhibited macrophage and neutrophils activation as } \\
\text { well as negatively affected monocyte and leukocyte } \\
\text { migration. }\end{array}$ & $(55)$ \\
\hline & $\begin{array}{l}\text { Tsaoko Fructus } \\
\text { (Methanolic extract) }\end{array}$ & $\begin{array}{l}\text { Had analgesic and } \\
\text { anti-inflammatory } \\
\text { properties. }\end{array}$ & nitric oxide & $\begin{array}{l}\text { Attenuated nitric oxide production in } \\
\text { lipopolysaccharide simulated BV2 microglia. }\end{array}$ & $(75)$ \\
\hline
\end{tabular}


TABLE 5 | Herbal medicine of HXF prescriptions used in the treatment of COVID-19 according to their effects, targets and mechanisms of action.

\begin{tabular}{|c|c|c|c|c|c|}
\hline $\begin{array}{l}\text { Herbal } \\
\text { formula }\end{array}$ & $\begin{array}{l}\text { Herbal medicine } \\
\text { (components) }\end{array}$ & Effects & Targets Gene & Mechanism of action & Reference \\
\hline \multirow[t]{8}{*}{ HXF } & $\begin{array}{l}\text { Ephedra sinica Stapf } \\
{[(+) \text {-catechin] }}\end{array}$ & $\begin{array}{l}\text { Inhibited the } \\
\text { growth of influenza } \\
\text { A PR8 virus }\end{array}$ & $\begin{array}{l}\text { endosomes and } \\
\text { lysosomes }\end{array}$ & $\begin{array}{l}\text { Inhibited the acidification of intracellular } \\
\text { compartments such as endosomes and } \\
\text { lysosomes. }\end{array}$ & (58) \\
\hline & $\begin{array}{l}\text { Cinnamomum cassia Presl } \\
\text { (Volatile oil, cinnamaldehyde) }\end{array}$ & $\begin{array}{l}\text { Had anti-influenza } \\
\text { virus activities in } \\
\text { the cellular level }\end{array}$ & $\begin{array}{l}\text { TLR7 signaling } \\
\text { pathway, IRAK-4, } \\
\text { IFN- } \beta\end{array}$ & $\begin{array}{l}\text { Activated TLR7 signaling pathway and } \\
\text { interleukin-1 related acceptor kinase- } 4 \\
\text { (IRAK-4). } \\
\text { Increased the expression of interferon- } \beta \text { (IFN- } \beta \text { ). }\end{array}$ & (76) \\
\hline & $\begin{array}{l}\text { Prunus armeniaca L. var. } \\
\text { ansu Maxim. } \\
\text { (Amygdalin) }\end{array}$ & $\begin{array}{l}\text { Slowed the } \\
\text { progression of } \\
\text { pulmonary fibrosis }\end{array}$ & $\begin{array}{l}\text { collagen I (Col1), } \\
\text { collagen III (Col3) }\end{array}$ & $\begin{array}{l}\text { Inhibited the expression of collagen I (Col1), } \\
\text { collagen III (Col3) }\end{array}$ & (59) \\
\hline & $\begin{array}{l}\text { Poria cocos (Schw.) Wolf. } \\
\text { (Polysaccharide) }\end{array}$ & $\begin{array}{l}\text { Enhanced humoral } \\
\text { and cellular } \\
\text { immunity }\end{array}$ & $\begin{array}{l}\text { Splenocytes,IL- } \\
12 p 70 \text { and } \\
\text { TNF- } \alpha\end{array}$ & $\begin{array}{l}\text { Improved proliferation of splenocytes. } \\
\text { Stimulated IL-12p70 and TNF- } \alpha \text { productions in } \\
\text { dendritic cells and macrophages. }\end{array}$ & (49) \\
\hline & $\begin{array}{l}\text { Pogostemon cablin (Blanco) } \\
\text { Benth. } \\
\text { (Patchouli alcohol) }\end{array}$ & $\begin{array}{l}\text { Anti-H1N1 } \\
\text { Influenza Virus }\end{array}$ & RLH pathway & $\begin{array}{l}\text { Inhibited the expression of cytokines and the } \\
\text { mRNA of RLH pathway. }\end{array}$ & (42) \\
\hline & $\begin{array}{l}\text { Eupatorium fortunei Turcz. } \\
\text { (flavonoids) }\end{array}$ & $\begin{array}{l}\text { Have antibacterial } \\
\text { activities }\end{array}$ & $\begin{array}{l}\text { Staphylo } \\
\text { tetragenus, } \\
\text { staphyloccocus } \\
\text { aureus,escherichia } \\
\text { coli and bacillus } \\
\text { subtilis }\end{array}$ & None & (71) \\
\hline & $\begin{array}{l}\text { Astragali Radix } \\
\text { (astragalus polysaccharide) }\end{array}$ & $\begin{array}{l}\text { Attenuated the } \\
\text { immune stress }\end{array}$ & $\begin{array}{l}\text { AMPK/SIRT-1 } \\
\text { signaling pathway }\end{array}$ & Activated the AMPK/SIRT-1 signaling pathway. & (77) \\
\hline & $\begin{array}{l}\text { Codonopsis Radix } \\
\text { (Codonopsis pilosula } \\
\text { polysaccharides) }\end{array}$ & $\begin{array}{l}\text { Ameliorated the } \\
\text { inflammatory } \\
\text { response }\end{array}$ & $\begin{array}{l}\text { IL-6, IL-8, and } \\
\text { TNF- } \alpha\end{array}$ & $\begin{array}{l}\text { Decreased levels of interleukin (IL)-6, IL-8, and } \\
\text { tumor necrosis factor (TNF)- } \alpha \text {. }\end{array}$ & (78) \\
\hline
\end{tabular}

Herbal medicine in targeting acute immune responses to SARSCoV-2 is shown in Figure 3.

\section{Targeting Pulmonary Fibrosis}

TZG was widely used for patients with COVID-19 who were in the recovery period and were at high risk of pulmonary fibrosis (PF). Using a network pharmacology analysis, we investigated the anti-pulmonary fibrosis mechanisms of TZG. Findings indicated that TZG could inhibit the expression of vascular endothelial growth factor (VEGF), TNF- $\alpha$, IL-6, MMP9, and TGF- $\beta 1$ via the VEGF, Toll-like receptor, MAPK, and TGF- $\beta 1$ signaling pathways. The binding ability and of herbal components to core protein targets was validated by molecular simulations. On molecular docking using Surflex-Dock modeling, a docking score of $>3$ signified a stable compound with strongbinding. Quercetin, kaempferol, and luteolin exhibited high binding activity to targets associated with PF. For example IL-6 (score $=3.0236,3.6316,3.7055$, respectively), TNF- $\alpha$ (score $=3.2116$, 3.9889, 5.9409, respectively), VEGF (score $=3.0175,3.844$, 3.1564, respectively), and MMP9 (score $=5.7384$, 3.079, 5.9618, respectively). Detailed blinding scores were shown in the Heat map in Figure 4, and the potential anti-pulmonary fibrosis mechanism of TZG is summarized in Figure 5.

\section{DISCUSSION}

In the battle of the epidemic in Wuhan, the clinical experience of TCM in COVID-19 patients can be used as a valuable reference. Tong proposed that the COVID-19 epidemic in Wuhan demonstrated cold-damp characteristics in terms of disease, environment, and the human body. The theory was proposed to interpret the characteristics of the epidemic from a TCM perspective, and to develop the treatment accordingly. Under the guidance of cold-damp plague theory, a series of TCM prescriptions, for varying stages, such as the mild, moderate, severe, critical, and recovery, were developed. TCM drugs, namely HZDP, LQG, HSYF, HXF, and TZG have been utilized in the treatment of COVID-19 patients (12-14). For suspected and diagnosed cases of COVID-19, HZDP+LQG was significantly more efficacious, when compared to LQG alone and western medicine; besides, it reduced the proportion of patients who progressed to severe. Although LQG and western medicine could alleviate cold symptoms, the HZDP+LQG group had a unique advantage in improving damp symptoms such as nausea, vomiting, and limb soreness. The results indicated the HZDP+LQG was effective in dispelling cold and removing dampness in patients with COVID-19. For mild and 
TABLE 6 | Herbal medicine of TZG used in the treatment of COVID-19 according to their effects, targets and mechanisms of action.

\begin{tabular}{|c|c|c|c|c|c|}
\hline $\begin{array}{l}\text { Herbal } \\
\text { formula }\end{array}$ & $\begin{array}{l}\text { Herbal medicine } \\
\text { (components) }\end{array}$ & Effects & Targets Gene & Mechanism of action & Reference \\
\hline \multirow[t]{11}{*}{ TZG } & $\begin{array}{l}\text { Astragali Radix } \\
\text { (Astragalus polysaccharide) }\end{array}$ & $\begin{array}{l}\text { Attenuated the immune } \\
\text { stress }\end{array}$ & $\begin{array}{l}\text { AMPK/SIRT-1 signaling } \\
\text { pathway }\end{array}$ & Activated the AMPK/SIRT-1 signaling pathway. & (77) \\
\hline & $\begin{array}{l}\text { Codonopsis Radix } \\
\text { (Codonopsis pilosula } \\
\text { polysaccharides) }\end{array}$ & $\begin{array}{l}\text { Ameliorated the } \\
\text { inflammatory response }\end{array}$ & IL-6, IL-8, and TNF- $\alpha$ & $\begin{array}{l}\text { Decreased levels of interleukin (IL)-6, IL-8, and } \\
\text { tumor necrosis factor (TNF)- } \alpha \text {. }\end{array}$ & (78) \\
\hline & Adenophorae Radix & $\begin{array}{l}\text { Enhanced } \\
\text { immunological function }\end{array}$ & $\begin{array}{l}\text { mononuclear } \\
\text { macrophages }\end{array}$ & $\begin{array}{l}\text { Enhanced the phagocytic function of mononuclear } \\
\text { macrophages. }\end{array}$ & (79) \\
\hline & $\begin{array}{l}\text { Glehniae Radix } \\
\text { (Imperatorin) }\end{array}$ & $\begin{array}{l}\text { Had anti-inflammatory } \\
\text { effects }\end{array}$ & iNOS and COX-2 & $\begin{array}{l}\text { Inhibited elevated iNOS and cyclooxygenase-2 } \\
\text { (COX-2) protein expression. }\end{array}$ & (80) \\
\hline & $\begin{array}{l}\text { Poria } \\
\text { (Polysaccharide) }\end{array}$ & $\begin{array}{l}\text { Enhanced humoral and } \\
\text { cellular immunity }\end{array}$ & $\begin{array}{l}\text { Splenocytes,IL-12p70 } \\
\text { and TNF- } \alpha\end{array}$ & $\begin{array}{l}\text { Improved proliferation of splenocytes. Stimulated } \\
\text { IL-12p70 } \\
\text { and TNF- } \alpha \text { productions in dendritic cells and } \\
\text { macrophages. }\end{array}$ & (49) \\
\hline & $\begin{array}{l}\text { Pinelliae Rhizoma } \\
\text { Praeparatum } \\
\text { (Alkaloid) }\end{array}$ & $\begin{array}{l}\text { Have protective effect } \\
\text { on pulmonary epithelial } \\
\text { cells }\end{array}$ & $\begin{array}{l}\text { NO,TNF- } \alpha, \mid L-8 \text { and } \\
\text { ICAM- } 1\end{array}$ & $\begin{array}{l}\text { Inhibited the release of NO, tumor necrosis factor- } \alpha \\
\text { (TNF- } \alpha \text { ). Inhibited the expression of interleukin } 8 \\
(\text { IL-8) and intercellular cell adhesion molecule- } 1 \\
\text { (ICAM-1). }\end{array}$ & (45) \\
\hline & $\begin{array}{l}\text { Fritillariae Thunbergii Bulbus } \\
\text { (Peimine) }\end{array}$ & $\begin{array}{l}\text { Had anti-inflammatory } \\
\text { effects }\end{array}$ & $\begin{array}{l}\text { TNF- } \alpha, \mathrm{IL}-6, \mathrm{IL}-1 \beta \text {, } \\
\mathrm{IL}-10, \mathrm{p} 38, \mathrm{ERK} \text { and } \\
\text { c-jun N-terminal kinase } \\
\text { (JNK) p65 and IkB }\end{array}$ & Blocked MAPKs and NF-кB signaling pathways. & (84) \\
\hline & $\begin{array}{l}\text { Paeoniae Radix Rubra } \\
\text { (Paeoniflorin) }\end{array}$ & Had antiarthritis effects & $\begin{array}{l}\text { Synoviocytes, IL-1, } \\
\text { PGE2, IL-6, VEGF, } \\
\text { GM-CSF,Gi, COX-2 }\end{array}$ & $\begin{array}{l}\text { Inhibited abnormal proliferation of synoviocytes and } \\
\text { the production of Interleukin-1 (IL-1), prostaglandin } \\
\text { E2 (PGE2), IL-6, vascular epidermal growth factor } \\
\text { (VEGF) and GM-CSF by synoviocytes and reducing } \\
\text { G protein (G i) and cyclo-oxygenase-2 (COX-2) } \\
\text { expression. }\end{array}$ & (85) \\
\hline & $\begin{array}{l}\text { Platycodonis Radix } \\
\text { (Platycodin D) }\end{array}$ & $\begin{array}{l}\text { Enhanced the } \\
\text { immunomodulatory } \\
\text { activities of mouse } \\
\text { lymphocytes and } \\
\text { macrophages }\end{array}$ & $\begin{array}{l}\text { Lymphocyte, } \\
\text { macrophage, IL-2, IL-4, } \\
\text { TNF- } \alpha\end{array}$ & $\begin{array}{l}\text { Promoted lymphocyte proliferation, enhanced } \\
\text { phagocytosis of macrophage, and stimulated } \\
\text { secretion of IL-2 and IL- } 4 \text { in lymphocyte and } \\
\text { secretion of TNF- } \alpha \text { and IL-12 in macrophages. }\end{array}$ & (50) \\
\hline & Saposhnikoviae Radix & $\begin{array}{l}\text { Modulated immune } \\
\text { functions }\end{array}$ & & $\begin{array}{l}\text { Increased nonspecific immunity and cell-mediated } \\
\text { immunity and improved the spleen proliferation } \\
\text { index. }\end{array}$ & (86) \\
\hline & $\begin{array}{l}\text { Glycyrrhizae Radix et } \\
\text { Rhizoma } \\
\text { (Glycyrrhizin) }\end{array}$ & $\begin{array}{l}\text { May reduce the severity } \\
\text { of an infection with } \\
\text { COVID-19 }\end{array}$ & ACE2 & Reduced the expression of ACE2 in the lung. & $(51,52)$ \\
\hline
\end{tabular}


TABLE 6 | Continued

\begin{tabular}{|c|c|c|c|c|c|}
\hline $\begin{array}{l}\text { Herbal } \\
\text { formula }\end{array}$ & $\begin{array}{l}\text { Herbal medicine } \\
\text { (components) }\end{array}$ & Effects & Targets Gene & Mechanism of action & Reference \\
\hline & $\begin{array}{l}\text { Fructus Hordei Germinatus } \\
\text { (glutamine-rich } \\
\text { protein, hemicellulose-rich } \\
\text { fiber) }\end{array}$ & $\begin{array}{l}\text { Reduced the epithelial } \\
\text { inflammatory response }\end{array}$ & STAT3, NFkB & $\begin{array}{l}\text { Depressed signal transducer and activator of } \\
\text { transcription } 3 \text { (STAT3) expression and inhibited } \\
\text { nuclear factor kappa B(NFkB) binding activity. }\end{array}$ & (74) \\
\hline & $\begin{array}{l}\text { Crataegi Fructus } \\
\text { (Maslinic acid) }\end{array}$ & $\begin{array}{l}\text { Has anti-inflammatory } \\
\text { properties }\end{array}$ & $\begin{array}{l}\text { hGIIA-sPLA2-induced } \\
\text { THP-1 cell }\end{array}$ & $\begin{array}{l}\text { Inhibited hGIIA-sPLA2-induced THP-1 cell } \\
\text { differentiation and migration. } \\
\text { Binded and inhibited hGIIA-sPLA2 enzymatic } \\
\text { activity. }\end{array}$ & (73) \\
\hline & \multicolumn{5}{|l|}{ Massa Medicata Fermentata } \\
\hline & $\begin{array}{l}\text { Rhizoma Dioscoreae } \\
\text { (Yam polysaccharides) }\end{array}$ & $\begin{array}{l}\text { Has } \\
\text { immunomodulatory } \\
\text { effects }\end{array}$ & IL-2, TNF- $\alpha$ & $\begin{array}{l}\text { Regulated the levels of IL-2 and TNF- } \alpha \text { in tumor } \\
\text { mice. }\end{array}$ & (87) \\
\hline
\end{tabular}

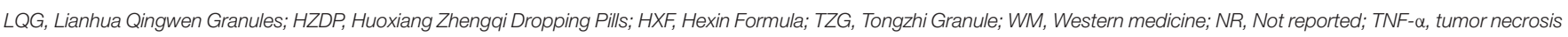

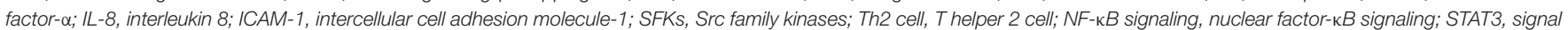

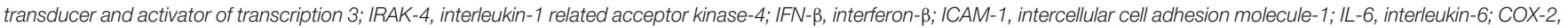
cyclooxygenase-2; IL-1 $\beta$, interleukin-1 $\beta$; IL-1, Interleukin-1; PGE2, prostaglandin E2; VEGF, vascular epidermal growth factor; COX-2, cyclo-oxygenase-2.

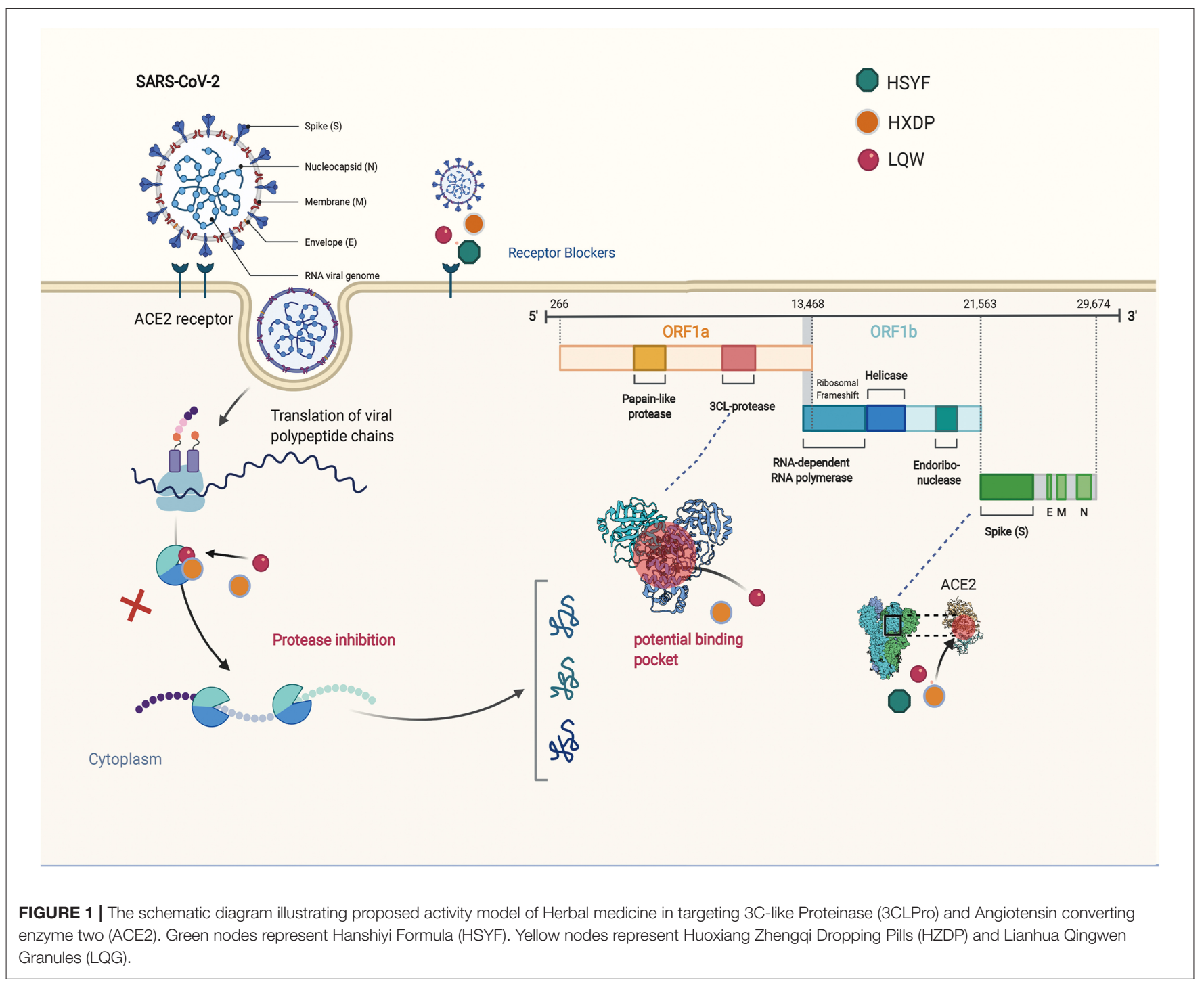




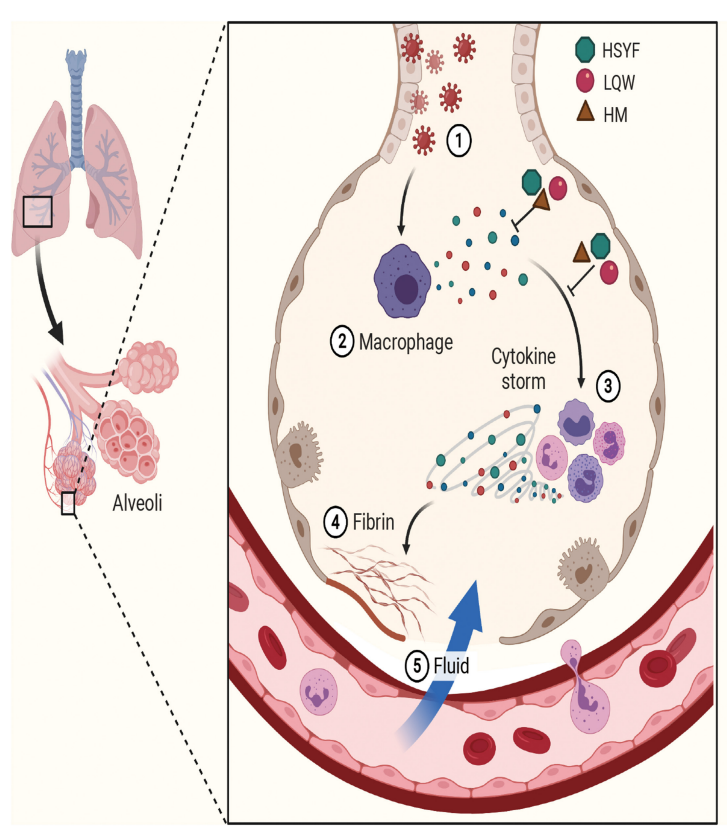

\section{Cytokine Storm}

(1) Coronavirus infects lung cells

(2) Immune cells, including

macrophages, identify the

virus and produce cytokines

(3) Cytokines attract more immune cells, such as white blood cells, which in turn produce more cytokines, creating a cycle of inflammation that damages the lung cells

(4) Damage can occur through the formation of fibrin

(5) Weakened blood vessels allow fluid to seep in and fill the lung cavities, leading to respiratory failure

FIGURE 2 | The schematic diagram illustrating proposed activity model of Herbal medicine in targeting cytokine. Green node represents Hanshiyi Formula (HSYF). Yellow node represents Huoxiang Zhengqi Dropping Pills (HZDP) and red node represents Lianhua Qingwen Granules (LQG).

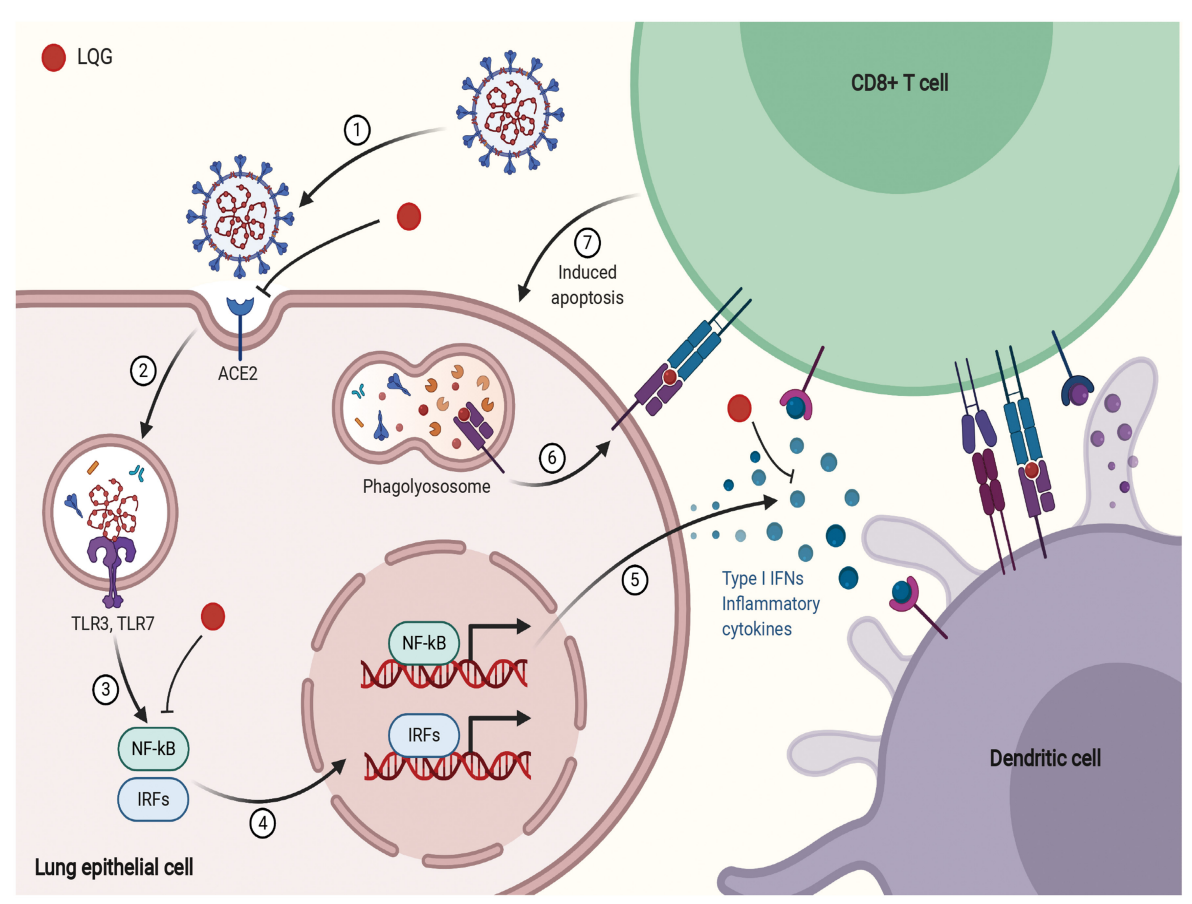

FIGURE 3 | The schematic diagram illustrating proposed activity model of Herbal medicine in targeting acute immune responses to SARS-CoV-2. Red node represents Lianhua Qingwen Granules (LQG).

moderate cases of COVID-19, HSYF was developed; it eliminated cold-dampness from the body and relieved lung inflammation. We founded that it significantly reduced the progression in mild and moderate COVID-19 cases to develop severe conditions, which indicated that HSYF may have positive effects in the treatment of the epidemic. For severe and critical patients, HXF was developed to dispel cold-dampness and invigorate healthy $q i$. We found that, with the use of HXF, the mortality in severe and critical cases could be reduced by $82.2 \%$ as estimated in a retrospective observational cohort study. For recurrent RT-PCR 


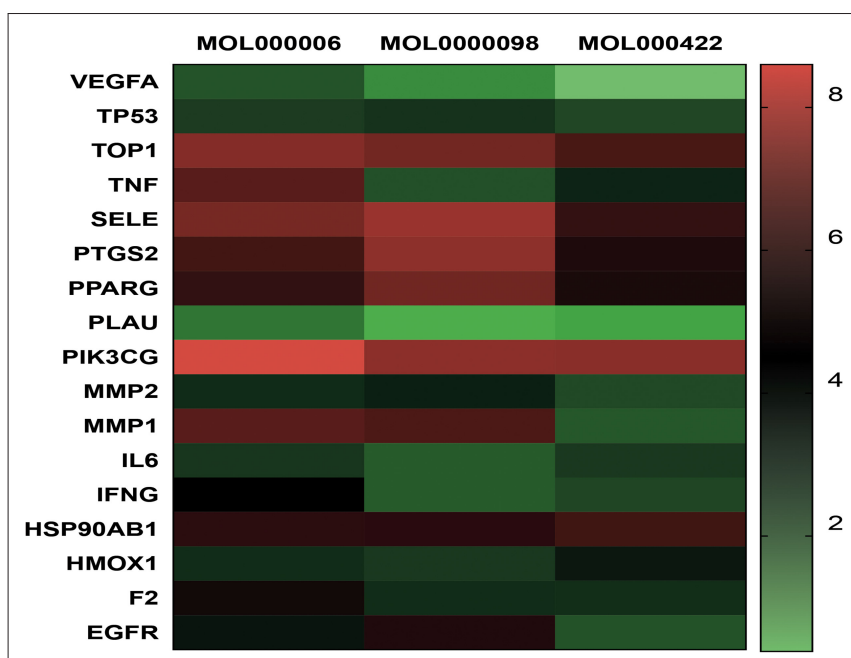

FIGURE 4 | Heat map of Molecular docking. Molecular models of the binding of quercetin (MOL0000098), kaempferol (MOL000422), luteolin (MOL000006) with TOP, MMP2, MMP9, IFNG, SELE, PLAU, VEGFA, HMOX1, F2, TNF, TP53, PPARG, PIK3CG, IL6, PTGS2, HSP90AB1, and EGFR, respectively.

positive cases, TZG was developed to supplement healthy qi and expel residual cold-damp pathogens from the body. TZG significantly reduced the RT-PCR test results to $2.8 \%$ in patients recovered from COVID-19.

Despite the fact that there is enough clinical evidences on the utility of TCM in COVID-19, the underlying mechanisms, from the perspective of modern science, are yet to be elucidated. Network pharmacology has provided a feasible reference. Network pharmacology revealed that HZDP can inhibit the replication of SARS-CoV-2 by interfering with the ACE2 enzyme and 3CL hydrolase (95). 3CLpro is a cysteine protease, a functional protein that mediates the hydrolysis of replicase polypeptides $1 \mathrm{a}$ and $1 \mathrm{ab}$ and during virus replication and proliferation (95). 3CLpro is highly conserved in its genes and produces RNA-dependent RNA polymerase ( $\mathrm{RdRp}$ ) during the replication of coronavirus. Therefore, 3CLpro can serve as a target for the drug design, and provide a breakthrough in the development of anti-SARS-COV-2 drugs $(37,38,91,97)$. According to the results of molecular docking, five components of HZDP could bind with SARS-COV-2 3CLpro; the binding ability was better than the control drug Remdesivir. LQD could exert anti-inflammatory activity to treat COVID-19, mainly through reducing the levels of inflammatory response factors IL8 , IL-17, IL-23 and TNF- $\alpha$, lowering the levels of IL- 8 and IL-17 in the blood, and inhibiting virus-induced activation of NF-kB and gene expression of IL-6, IL-8, TNF-a, and IP-10, which can reduce the inflammatory response and slow down the damage of inflammatory response exudate to lung function $(94,96,104)$.

The arachidonic acid metabolic pathway mediates the production of a variety of inflammatory response factors (120122). Inhibiting this may decrease inflammation in patients with COVID-19. For mild and moderate COVID-19 cases, HSYF successfully reduced the progression to severe status, and alleviated symptoms in patients by exerting anti-viral effect, immune regulation and anti-inflammatory pathways (90). A correlation between blood glucose control and prognosis in patients with co-existing COVID-19 and diabetes has been reported (123); HSYF could target the AGE-RAGE signaling pathway in such patients. Molecular docking indicated that quercetin and luteolin, and L-tyrosine and L-phenylalanine had good binding activities to IL6 and ACE2, respectively. IL-6 levels can assist in understanding the progression of infectious diseases and the response to treatment (124). All these potential mechanisms may be related to the therapeutic effect of HSYF.

Notably, in patients who have experienced and survived a COVID-19, PF has been observed, which may progress to chronic and severe interstitial lung disease. A meta-analysis showed that there is an obvious association between the development of PF and respiratory viral infections (125). It is well-known that SARSCoV-2 invades host cells and interacts with ACE2; ACE2 is highly expressed in type II lung cells and directly participates in the occurrence and development of inflammation and PF $(126,127)$. Preventing the occurrence of $\mathrm{PF}$ in patients recovering from SARS-CoV-2 infection is of vital importance. TZG is formulated for fibrosis in COVID-19 patients at the recovery stage.

The pathological process of PF can be roughly divided into three stages. The first is the diffuse damage of vascular endothelial cells and alveolar epithelial cells by pathogenic factors, which initiates the inflammatory immune response. Second, a variety of inflammatory cells release various cytokines and inflammatory mediators, expanding tissue damage and causing interstitial hyperplasia. The third is the migration and proliferation of fibroblasts and endothelial cells, and the metabolic disorders of collagen and other extracellular matrices, which aggravate inflammatory damage and proliferation in a feedback manner. Eventually, the process could lead to the replacement and reconstruction of normal lung tissue. These processes involved in these stages exist simultaneously (128), and their interaction generates other mediators involved in the inflammatory response, such as TNF- $\alpha$ and IL-6, which directly or indirectly promote the synthesis of ECM through interaction with other cytokines (129). More importantly, several studies have robustly documented that silencing the expression of TGF$\beta 1$ reduces inflammation and slows the progression of PF (130). Network pharmacology suggested that TZG can reduce the expression of TGF- $\beta 1, \alpha$-smooth muscle actin ( $\alpha$-SMA) and TNF- $\alpha$, and inhibit alveolar cell apoptosis, and hence reduce lung inflammation and fibrosis damage.

In this review, we explained COVID-19 in Wuhan, according to the cold-dampness theory of TCM, and offered a series of clinical evidence to support our opinion. Furthermore, the underlying mechanisms, in the light of modern pharmacology, were discussed to support the utility and efficacy of TCM. However, there are limitations. First, since COVID-19 is a global pandemic that has been widely spread in countries with different climates, the cold-damp nature of the epidemic in Wuhan cannot represent the characteristics of the disease in other regions of the world. One point of view to explain the epidemic transmission of people in hot and humid areas of the globe is that increased humidity in the atmosphere could 


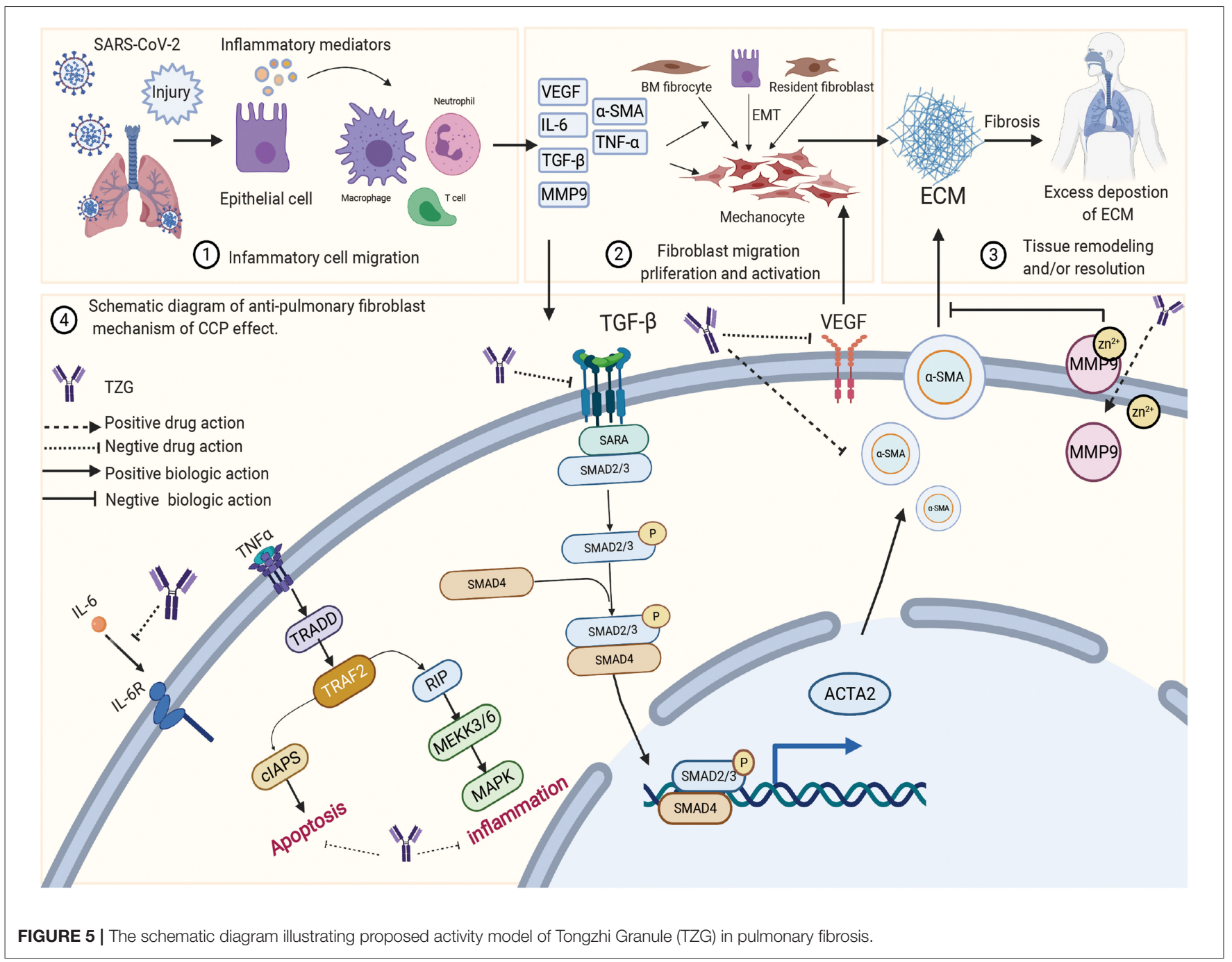

reduce the air temperature, thus indirectly influencing disease susceptibility (25). Despite meteorological, environmental and etiological factors related to the disease, physical defense measures such as face masks, social distancing, and contact tracing are also important factors affecting the transmission and progression of the epidemic (131). Thus, in this review, we adopted cluster study approaches by enrolling COVID19 patients in the Wuhan area, to provide objective clinical evidence for TCM treatments, guided by the theory of colddampness plague. Second, although the clinical efficacy of these TCM prescriptions guided by cold-damp plague theory has been confirmed clinically as well as network pharmacology, there is still a lack of high-level evidence to evaluate the effectiveness and safety of the TCMs. The mechanisms of these drugs have been elucidated based on network pharmacology and molecular docking speculations, which have not yet been experimentally verified. In response to the above problems, the effectiveness and safety of TCM in the treatment of COVID-19 needs to be further evaluated in a large-scale RCT. Further, the anti-coronavirus mechanisms should be further verified through cell experiments, animal experiments, and multi-omics studies, which can provide the basis for new drug development of COVID-19, and also provide a new option for the prevention and control of the epidemic.

\section{AUTHOR CONTRIBUTIONS}

YZhe and DJ wrote the draft of the manuscript and contributed equally to this work. FL and XT designed the study and as the corresponding authors. JL, YZha, and JT participated in the revision of the manuscript. All authors contributed to the article and approved the submitted version.

\section{ACKNOWLEDGMENTS}

This research was supported by the Special Project for Emergency of the Ministry of Science and Technology of China (2020YFC0845000) and Special Project for Emergency of the National Administration of Tradition Chinese Medicine of China (2020ZYLCYJ04-1). 


\section{REFERENCES}

1. Wang C, Horby PW, Hayden FG, Gao GF. A novel coronavirus outbreak of global health concern. Lancet. (2020) 395:4703. doi: 10.1016/S0140-6736(20)30185-9

2. Lai CC, Shih TP, Ko WC, Tang HJ, Hsueh PR. Severe acute respiratory syndrome coronavirus 2 (SARS-CoV-2) and coronavirus disease-2019 (COVID-19): the epidemic and the challenges. Int J Antimicrob Agents. (2020) 55:105924. doi: 10.1016/j.ijantimicag.2020.105924

3. Holshue ML, DeBolt C, Lindquist S, Lofy KH, Wiesman J, Bruce H, et al. First case of 2019 novel coronavirus in the United States. N Engl J Med. (2020) 382:929-36. doi: 10.1056/NEJMoa2001191

4. Okada P, Buathong R, Phuygun S, Thanadachakul T, Parnmen S, Wongboot W, et al. Early transmission patterns of coronavirus disease 2019 (COVID19) in travellers from Wuhan to Thailand, January 2020. Euro Surveill. (2020) 25:2000097. doi: 10.2807/1560-7917.ES.2020.25.8.2000097

5. Bernard Stoecklin S, Rolland P, Silue Y, Mailles A, Campese C, Simondon A, et al. First cases of coronavirus disease 2019 (COVID-19) in France: surveillance, investigations and control measures, January 2020. Euro Surveill. (2020) 25:2000094. doi: 10.2807/1560-7917.ES.2020.25.6.2000094

6. Huang C, Wang Y, Li X, Ren L, Zhao J, Hu Y, et al. Clinical features of patients infected with 2019 novel coronavirus in Wuhan, China. Lancet. (2020) 395:497-506. doi: 10.1016/S0140-6736(20)30183-5

7. WHO. Novel Coronavirus Situation Dashboard Geneva, Switzerland. (2020). Available online at: https://covid19.who.int/ (accessed September 19, 2020).

8. Ren JL, Zhang AH, Wang XJ. Traditional Chinese medicine for COVID-19 treatment. Pharmacol Res. (2020) 155:104743. doi: 10.1016/j.phrs.2020.104743

9. China NHCotPsRo. Notice on the Issuance of the Fifth Edition of the Diagnosis and Treatment Guideline for COVID-19 (Trial Version). (2020). Available online at: http://www.nhc.gov.cn/yzygj/s7653p/202008/ 0a7bdf12bd4b46e5bd28ca7f9a7f5e5a.shtml (accessed September 19, 2020).

10. News U. Participation rate of Chinese Medicine Treatment of COVID-19 Reached $92.36 \%$ [Participation rate of Chinese medicine treatment of new coronary pneumonia reached 92.36\%]. (2020). Available online at: https:// kuaibao.qq.com/s/20200306A0VXI900?refer=spider (accessed September 19, 2020).

11. Lee DYW, Li QY, Liu J, Efferth T. Traditional Chinese herbal medicine at the forefront battle against COVID-19: Clinical experience and scientific basis. Phytomedicine. (2021) 80:153337. doi: 10.1016/j.phymed.2020.153337

12. Xiao M, Tian J, Zhou Y, Xu X, Min X, Lv Y, et al. Efficacy of Huoxiang Zhengqi dropping pills and Lianhua Qingwen granules in treatment of COVID-19: a randomized controlled trial. Pharmacol Res. (2020) 161:105126. doi: 10.1016/j.phrs.2020.105126

13. Tian J, Yan S, Wang H, Zhang Y, Zheng Y, Wu H, et al. Hanshiyi Formula, a medicine for Sars-CoV2 infection in China, reduced the proportion of mild and moderate COVID-19 patients turning to severe status: A cohort study. Pharmacol Res. (2020) 161:105127. doi: 10.1016/j.phrs.2020.105127

14. Chen G, Su W, Yang J, Luo D, Xia P, Jia W, et al. Chinese herbal medicine reduces mortality in patients with severe and critical Coronavirus disease 2019: a retrospective cohort study. Front Med. (2020) 14:7529. doi: 10.1007/s11684-020-0813-6

15. He S, Tian J, Li X, Zhou Y, Xiao M, Zhang Y, et al. Positive RT-PCR test results in 420 patients recovered from COVID-19 in Wuhan: an observational study. Front Pharmacol. (2020) 11:1574. doi: 10.3389/fphar.2020.549117

16. Ding Y, Zeng L, Li R, Chen Q, Zhou B, Chen Q, et al. The Chinese prescription lianhuaqingwen capsule exerts anti-influenza activity through the inhibition of viral propagation and impacts immune function. BMC Complement Altern Med. (2017) 17:130. doi: 10.1186/s12906-0171585-7

17. Runfeng L, Yunlong $\mathrm{H}$, Jicheng $\mathrm{H}$, Weiqi P, Qinhai M, Yongxia S, et al. Lianhuaqingwen exerts anti-viral and anti-inflammatory activity against novel coronavirus (SARS-CoV-2). Pharmacol Res. (2020) 156:104761. doi: 10.1016/j.phrs.2020.104761

18. Biryukov J, Boydston JA, Dunning RA, Yeager JJ, Wood S, Reese $\mathrm{AL}$, et al. Increasing temperature and relative humidity accelerates inactivation of SARS-CoV-2 on surfaces. mSphere. (2020) 5:e0044120. doi: 10.1128/mSphere.00441-20
19. Hosseini V. SARS-CoV-2 Virulence: interplay of floating virusladen particles, climate, and humans. Adv Biosyst. (2020) 4:e2000105. doi: 10.1002/adbi.202000105

20. Rouen A, Adda J, Roy O, Rogers E, Lévy P. COVID-19: relationship between atmospheric temperature and daily new cases growth rate. Epidemiol Infect. (2020) 148:e184. doi: 10.1017/S0950268820001831

21. Liu P, Yang M, Zhao X, Guo Y, Wang L, Zhang J, et al. Cold-chain transportation in the frozen food industry may have caused a recurrence of COVID-19 cases in destination: successful isolation of SARS-CoV-2 virus from the imported frozen cod package surface. Biosaf Health. (2020) 2:199-201. doi: 10.1016/j.bsheal.2020.11.003

22. Han J, Zhang X, He S, Jia P. Can the coronavirus disease be transmitted from food? A review of evidence, risks, policies and knowledge gaps. Environ Chem Lett. (2020). doi: 10.1007/s10311-020-01101-x. [Epub ahead of print].

23. Bueckert M, Gupta R, Gupta A, Garg M, Mazumder A. Infectivity of SARS-CoV-2 and other coronaviruses on dry surfaces: potential for indirect transmission. Materials (Basel). (2020) 13:22. doi: 10.3390/ma13225211

24. Sarkodie SA, Owusu PA. Impact of meteorological factors on COVID-19 pandemic: evidence from top 20 countries with confirmed cases. Environ Res. (2020) 191:110101. doi: 10.1016/j.envres.2020.110101

25. Lakshmi Priyadarsini S, Suresh M. Factors influencing the epidemiological characteristics of pandemic COVID 19: a TISM approach. Int J Healthc Manage. (2020) 13:89-98. doi: 10.1080/20479700.2020.1755804

26. Song P, Zhao L, Li X, Su J, Jiang Z, Song B, et al. Interpretation of the Traditional Chinese Medicine portion of the diagnosis and treatment protocol for corona virus disease 2019 (Trial Version 7). J Tradit Chin Med. (2020) 40:497-508. doi: 10.19852/j.cnki.jtcm.2020.03.019

27. Shaw B, Daskareh M, Gholamrezanezhad A. The lingering manifestations of COVID-19 during and after convalescence: update on long-term pulmonary consequences of coronavirus disease 2019 (COVID-19). Radiol Med. (2020). doi: 10.1007/s11547-020-01295-8. [Epub ahead of print].

28. Li H, Lu CZ, Tang KC. Clinical observation on treatment of SARS with combination of chaihu droplet pill and huoxiang zhengqi droplet pill. Zhongguo Zhong Xi Yi Jie He Za Zhi. (2004) 24:321-4.

29. Jia W, Wang C, Wang Y, Pan G, Jiang M, Li Z, et al. Qualitative and quantitative analysis of the major constituents in Chinese medical preparation Lianhua-Qingwen capsule by UPLC-DAD-QTOF-MS. ScientificWorldJournal. (2015) 2015:731765. doi: 10.1155/2015/731765

30. Wu L, Chen Y, Ma Y, Yang Z, Yang $N$, Deng $W$, et al. Clinical practice guideline on treating influenza in adult patients with Chinese patent medicines. Pharmacol Res. (2020) 160:105101. doi: 10.1016/j.phrs.2020.105101

31. Huang FKP. Coronavirus Symptoms: Defining Mild, Moderate and Severe. (2020). Available online at: https://www.mprnews.org/story/2020/03/13/ npr-coronavirus-symptoms-defining-mild-moderate-and-severe (accessed September 19, 2020).

32. Wang Z, Chen X, Lu Y, Chen F, Zhang W. Clinical characteristics and therapeutic procedure for four cases with 2019 novel coronavirus pneumonia receiving combined Chinese and Western medicine treatment. Biosci Trends. (2020) 14:64-8. doi: 10.5582/bst.2020.01030

33. Zhu N, Zhang D, Wang W, Li X, Yang B, Song J, et al. A novel coronavirus from patients with pneumonia in China, 2019. N Engl J Med. (2020) 382:72733. doi: 10.1056/NEJMoa2001017

34. Gadlage MJ, Graham RL, Denison MR. Murine coronaviruses encoding nsp2 at different genomic loci have altered replication, protein expression, and localization. J Virol. (2008) 82:11964-9. doi: 10.1128/JVI.01126-07

35. Masters PS. The molecular biology of coronaviruses. Advanc Virus Res. (2006) 66:193-292. doi: 10.1016/S0065-3527(06)66005-3

36. Ziebuhr J, Snijder EJ, Gorbalenya AE. Virus-encoded proteinases and proteolytic processing in the Nidovirales. J Gen Virol. (2000) 81:85379. doi: 10.1099/0022-1317-81-4-853

37. Zumla A, Chan JFW, Azhar EI, Hui DSC, Yuen KY. Coronaviruses - drug discovery and therapeutic options. Nat Rev Drug Discov. (2016) 15:32747. doi: 10.1038/nrd.2015.37

38. Sheahan TP, Sims AC, Graham RL, Menachery VD, Gralinski LE, Case JB, et al. Broad-spectrum antiviral GS-5734 inhibits both epidemic and zoonotic coronaviruses. Sci Transl Med. (2017) 9:396. doi: 10.1126/scitranslmed.aal3653 
39. Xinkui L, Jiarui W, Dan Z, Kaihuan W, Xiaojiao D, Xiaomeng Z. A network pharmacology approach to uncover the multiple mechanisms of hedyotis diffusa willd on colorectal cancer. Evid Based Complement Alternat Med. (2018) 2018:1-12. doi: 10.1155/2018/6517034

40. Gao L, Hao J, Niu Y-Y, Tian M, Yang X, Zhu C-H, et al. Network pharmacology dissection of multiscale mechanisms of herbal medicines in stage IV gastric adenocarcinoma treatment. Medicine. (2016) 95:e4389. doi: 10.1097/MD.0000000000004389

41. Du G, Wang Y, Ran Z, Tan C, He X, Hu J, et al. Multi-target and multicomponent pattern, a superficial understanding of the action mechanism of Traditional Chinese Medicine. World Sci Technol. (2009) 4:10-14.

42. Wu XL, Ju DH, Chen J, Yu B, Liu KL, He JX, et al. Immunologic mechanism of Patchouli alcohol anti-H1N1 influenza virus may through regulation of the RLH signal pathway in vitro. Curr Microbiol. (2013) 67:431-6. doi: 10.1007/s00284-013-0381-y

43. Chen QH, Yu F, Wang HM, Ding XR, Zhu J, Liu YS, et al. Effects of Atractylenolide I, Atractylenolide II and Atractylenolide III on cytokines expression of inflammatory macrophages. Chin Pharmacist. (2017) 20: 2112-6. (in chinese).

44. Xu J, Lu X, Han F. Effects of honokiol on particulate matter 2.5-induced lung injury in asthmatic mice and its mechanisms. Zhong Nan Da Xue Xue Bao Yi Xue Ban. (2018) 43:718-24. doi: 10.11817/j.issn.1672-7347.2018.07.004

45. Wu WB, Zhu CY, Luo C. Research on the protective effect of Alkaloids Pinelliaf Rhizoma on inflammatory injury of pulmonary epithelial cells. J Inner Mong Agric Univ. (2018) 39:1-8. doi: 10.16853/j.cnki.1009-3575.2018.04.001

46. Chen CY, Leu YL, Fang Y, Lin CF, Kuo LM, Sung WC, et al. Antiinflammatory effects of Perilla frutescens in activated human neutrophils through two independent pathways: Src family kinases and Calcium. Sci Rep. (2015) 5:18204. doi: 10.1038/srep18204

47. Lee HJ, Lee H, Kim MH, Choi YY, Ahn KS, Um JY, et al. Angelica dahurica ameliorates the inflammation of gingival tissue via regulation of pro-inflammatory mediators in experimental model for periodontitis. $J$ Ethnopharmacol. (2017) 205:16-21. doi: 10.1016/j.jep.2017.04.018

48. Zhuo XM, Zhao Y, He CC, Li JX. Preventive effects of Citrus reticulata essential oil on bleomycin-induced pulmonary fibrosis in rats and the mechanism. J Chin Integr Med. (2012) 10:200-9. doi: 10.3736/jcim20120211

49. Wu Y, Li S, Li H, Zhao C, Ma H, Zhao X, et al. Effect of a polysaccharide from Poria cocos on humoral response in mice immunized by H1N1 influenza and HBsAg vaccines. Int J Biol Macromol. (2016) 91:24857. doi: 10.1016/j.ijbiomac.2016.05.046

50. Qiu XF, Sun D. Effect study on total Saponins in Platycodi radix for mice with respiratory syncytial virus pneumonia via inhibition of IRG-1. J New Chin Med. (2020) 52:1-5.

51. Final report on the safety assessment of Glycyrrhetinic Acid, Potassium Glycyrrhetinate, Disodium Succinoyl Glycyrrhetinate, Glyceryl Glycyrrhetinate, Glycyrrhetinyl Stearate, Stearyl Glycyrrhetinate, Glycyrrhizic Acid, Ammonium Glycyrrhizate, Dipotassium Glycyrrhizate, Disodium Glycyrrhizate, Trisodium Glycyrrhizate, Methyl Glycyrrhizate, and Potassium Glycyrrhizinate. Int J Toxicol. (2007) 26(Suppl. 2):79-112. doi: 10.1080/10915810701351228

52. Murck H. Symptomatic protective action of glycyrrhizin (Licorice) in COVID-19 infection? Front Immunol. (2020) 11:1239. doi: 10.3389/fimmu.2020.01239

53. Ji X, Peng Q, Li H, Liu F, Wang M. Chemical characterization and antiinflammatory activity of polysaccharides from Zizyphus jujube cv. Muzao. Int J Food Eng. (2017) 13:20160382. doi: 10.1515/ijfe-2016-0382

54. Khan S, Mehmood MH, Ali ANA, Ahmed FS, Dar A, Gilani AH. Studies on anti-inflammatory and analgesic activities of betel nut in rodents. $J$ Ethnopharmacol. (2011) 135:654-61. doi: 10.1016/j.jep.2011.03.064

55. Ezzat SM, Ezzat MI, Okba MM, Menze ET, Abdel-Naim AB. The hidden mechanism beyond ginger (Zingiber officinale Rosc.) potent in vivo and in vitro anti-inflammatory activity. J Ethnopharmacol. (2018) 214:11323. doi: $10.1016 /$ j.jep.2017.12.019

56. Deng L, Pang P, Zheng K, Nie J, Xu H, Wu S, et al. Forsythoside A controls Influenza A virus infection and improves the prognosis by inhibiting virus replication in mice. Molecules. (2016) 21:524. doi: $10.3390 /$ molecules 21050524
57. Ding Y, Cao Z, Cao L, Ding G, Wang Z, Xiao W. Antiviral activity of chlorogenic acid against influenza $\mathrm{A}(\mathrm{H} 1 \mathrm{~N} 1 / \mathrm{H} 3 \mathrm{~N} 2)$ virus and its inhibition of neuraminidase. Sci Rep. (2017) 7:45723. doi: 10.1038/srep45723

58. Mantani N, Imanishi N, Kawamata H, Terasawa K, Ochiai H. Inhibitory effect of (+)-catechin on the growth of influenza A/PR/8 virus in MDCK cells. Planta Med. (2001) 67:240-3. doi: 10.1055/s-2001-12009

59. Du HK, Song FC, Zhou X, Li H, Zhang JP. Efect of amygdlin on serum proteomic biomarker in pulmonary fibrosis of bleomycin-induced rat. Zhonghua Lao Dong Wei Sheng Zhi Ye Bing Za Zhi. (2010) 28:260-3. doi: 10.3760/cma.j.issn.1001-9391.2010.04.005

60. Kim W, Lee W, Huh E, Choi E, Jang YP, Kim YK, et al. Ephedra sinica Stapf and Gypsum Attenuates Heat-Induced Hypothalamic Inflammation in Mice. Toxins (Basel). (2019) 12:16. doi: 10.3390/toxins12010016

61. Liang X, Huang Y, Pan X, Hao Y, Chen X, Jiang H, et al. Erucic acid from Isatis indigotica Fort suppresses influenza A virus replication and inflammation in vitro and in vivo through modulation of NFkappaB and p38 MAPK pathway. J Pharm Anal. (2020) 10:13046. doi: 10.1016/j.jpha.2019.09.005

62. LI,K, Yang Q, Zhou TT, Yan SC, Weng XG, Yang L, et al. Protective effects of phenolic compound of Osmundae Rhizoma on systemic inflammatory response syndrome in mice. Chin J Exp Tradit Med Formulae. (2019) 25:55-60. doi: 10.13422/j.cnki.syfjx.20190909

63. Lu Y, Jiang Y, Ling L, Zhang Y, Li H, Chen D. Beneficial effects of Houttuynia cordata polysaccharides on "two-hit" acute lung injury and endotoxic fever in rats associated with anti-complementary activities. Acta Pharm Sin B. (2018) 8:218-27. doi: 10.1016/j.apsb.2017.11.003

64. Wang QW, Su Y, Sheng JT, Gu LM, Zhao Y, Chen XX, et al. Anti-influenza A virus activity of rhein through regulating oxidative stress, TLR4, Akt, MAPK, and NF-kB signal pathways. PLoS ONE. (2018) 13:e0191793. Epub 2018/02/01. doi: 10.1371/journal.pone.0191793

65. Ye SS, Zeng YY, Yin LL. Effects of salidroside on proliferation, apoptosis, phagocytosis, ROS and NO production of murine peritoneal macrophages in vitro. Chin J Cell Mol Imm. (2011) 27:237-41. doi: $10.13423 /$ j.cnki.cjcmi.005891

66. Schuhmacher A, Reichling J, Schnitzler P. Virucidal effect of peppermint oil on the enveloped viruses herpes simplex virus type 1 and type 2 in vitro. Phytomedicine. (2003) 10:504-10. doi: 10.1078/094471103322331467

67. Li,LC, Piao HM, Qin XZ, Yan GH, Li GZ. Effects of extract of notopterygium on Th1/Th2 cells balance and p38 signaling pathway in the asthma mouse model. Acta Anatomica Sinica. (2013) 44:819-23. doi: 10.3969/j.issn.0529-1356.2013.06.016

68. Kim SB, Seo YS, Kim HS, Lee AY, Chun JM, Moon BC, et al. Antiasthmatic effects of lepidii seu Descurainiae Semen plant species in ovalbumin-induced asthmatic mice. J Ethnopharmacol. (2019) 244:112083. doi: 10.1016/j.jep.2019.112083

69. Huang CQ, Li W, Wu B, Chen WM, Chen LH, Mo GW, et al. Pheretima aspergillum decoction suppresses inflammation and relieves asthma in a mouse model of bronchial asthma by NF-kB inhibition. J Ethnopharmacol. (2016) 189:22-30. doi: 10.1016/j.jep.2016.05.028

70. Kim W, Oh TS, Park YJ. Anti-viral effect of herbal medicine Korean traditional cynanchum paniculatum (BGE.) kitag extracts. Afr J Tradit Complement Altern Med. (2017) 14:194-8. doi: 10.21010/ajtcam.v14i3.21

71. Liu J, Jin Y. Study on extracting condition of flavonoids from eupatorium Fortunei Turez and its antibacterial activities. Shanghai Chem Ind. (2012) 37:15-7. doi: 10.16759/j.cnki.issn.1004-017x.2012.01.008

72. Li YX, Li RH. Anti-inflammatory activity of volatile oil extracted from Atractylodes lancea. J Liaon Univ Tradit Chin. (2013) 15:71-2.

73. Yap WH, Ahmed N, Lim YM. Inhibition of human group IIA-secreted Phospholipase A2 and THP-1 monocyte recruitment by maslinic acid. Lipids. (2016) 51:1153-9. doi: 10.1007/s11745-016-4186-1

74. Kanauchi O, Serizawa I, Araki Y, Suzuki A, Andoh A, Fujiyama Y, et al. Germinated barley foodstuff, a prebiotic product, ameliorates inflammation of colitis through modulation of the enteric environment. J Gastroenterol. (2003) 38:134-41. doi: 10.1007/s005350300022

75. Lee KY, Kim SH, Sung SH, Kim YC. Inhibitory constituents of lipopolysaccharide-induced nitric oxide production in BV2 microglia isolated from Amomum tsao-ko. Planta Med. (2008) 74:867-9. doi: $10.1055 / \mathrm{s}-2008-1074552$ 
76. Liu R, He T, Zeng N, Chen T, Gou L, Liu JW. Mechanism of anti-influenza virus of volatile oil in Cinnamomi Ramulus and cinnamaldehyde. Chin Tradit Herb Drugs. (2013) 44:14604. doi: 10.7501/j.issn.0253-2670.2013.11.019

77. Liu D, Su J, Lin J, Qian G, Chen X, Song S, et al. Activation of AMPKdependent SIRT-1 by astragalus polysaccharide protects against ochratoxin A-induced immune stress in vitro and in vivo. Int J Biol Macromol. (2018) 120:683-92. doi: 10.1016/j.ijbiomac.2018.08.156

78. Chu X, Liu XJ, Qiu JM, Zeng XL, Bao HR, Shu J. Effects of Astragalus and Codonopsis pilosula polysaccharides on alveolar macrophage phagocytosis and inflammation in chronic obstructive pulmonary disease mice exposed to PM2.5. Environ Toxicol Pharmacol. (2016) 48:7684. doi: 10.1016/j.etap.2016.10.006

79. Gong XJ, Ji H, Li P, Yang L, Chen YD, Mao XW. Studies of Radix adenophorae extracts on antitussive-expectorant and immunoenhancement effects. Chin J Mod Appl Pharm. (2000) 17:258-60. doi: 10.13748/j.cnki.issn1007-7693.2000.04.002

80. Huang GJ, Deng JS, Liao JC, Hou WC, Wang SY, Sung PJ, et al. Inducible nitric oxide synthase and cyclooxygenase-2 participate in anti-inflammatory activity of imperatorin from Glehnia littoralis. J Agric Food Chem. (2012) 60:1673-81. doi: 10.1021/jf204297e

81. Xiong S-L, Hou D-B, Huang N, Li A. Preparation and biological activity of saponin from Ophiopogon japonicus. Afr J Pharm Pharmacol. (2012) 6:1964-70. doi: 10.5897/AJPP12.484

82. Lu WQ, Qiu Y, Li TJ, Tao X, Sun LN, Chen WS. Timosaponin BII inhibits pro-inflammatory cytokine induction by lipopolysaccharide in BV2 cells. Arch Pharm Res. (2009) 32:1301-8. doi: 10.1007/s12272-0091916-4

83. Han C, Yang J, Song P, Wang X, Shi W. Effects of Salvia miltiorrhiza polysaccharides on lipopolysaccharide-induced inflammatory factor release in RAW264.7 cells. J Interferon Cytokine Res. (2018) 38:29-37. doi: 10.1089/jir.2017.0087

84. Yi PF, Wu YC, Dong HB, Guo Y, Wei Q, Zhang C, et al. Peimine impairs pro-inflammatory cytokine secretion through the inhibition of the activation of NF-кB and MAPK in LPS-induced RAW264.7 macrophages. Immunopharmacol Immunotoxicol. (2013) 35:567-72. doi: 10.3109/08923973.2013.822508

85. Zheng YQ, Wei W, Zhu L, Liu JX. Effects and mechanisms of Paeoniflorin, a bioactive glucoside from paeony root, on adjuvant arthritis in rats. Inflamm Res. (2007) 56:182-8. doi: 10.1007/s00011-006-6002-5

86. Liu H, Tian JM, sun L, Bai XM, Li XJ, Jia TJ. Reactions of macrophage and lymphocyte subsets in normal mice to Radix Saposhnikoviae Polysaccharide. Chin J Tissue Eng Res. (2008) 12:3475-8.

87. Xu YZ, Pang HL, Li HY, Fan JC. Research on anti-tumor and immunomodulatory effects of Yam polysaccharides on tumor mice. J Med Forum. (2020) 41:8-10.

88. Missiuro PV, Liu K, Zou L, Ross BC, Zhao G, Liu JS, et al. Information flow analysis of interactome networks. PLoS Comput Biol. (2009) 5:e1000350. doi: 10.1371/journal.pcbi.1000350

89. Mering Cv, Huynen M, Jaeggi D, Schmidt S, Bork P, Snel B. STRING: a database of predicted functional associations between proteins. Nucleic Acids Res. (2003) 31:258-61. doi: 10.1093/nar/gkg034

90. Han L, Wei XX, Zheng YJ, Zhang LL, Wang XM, Yang HY, et al. Potential mechanism prediction of Cold-Damp Plague Formula against COVID-19 via network pharmacology analysis and molecular docking. Chin Med. (2020) 15:78. doi: 10.1186/s13020-020-00360-8

91. Liu F, Li L, Xu M, Wu J, Luo D, Zhu Y, et al. Prognostic value of interleukin6, C-reactive protein, and procalcitonin in patients with COVID-19. J Clin Virol. (2020) 127:104370. doi: 10.1016/j.jcv.2020.104370

92. Zhang H, Penninger JM, Li Y, Zhong N, Slutsky AS. Angiotensinconverting enzyme 2 (ACE2) as a SARS-CoV-2 receptor: molecular mechanisms and potential therapeutic target. Int Care Med. (2020) 46:58690. doi: 10.1007/s00134-020-05985-9

93. Zhou P, Yang X-L, Wang X-G, Hu B, Zhang L, Zhang W, et al. A pneumonia outbreak associated with a new coronavirus of probable bat origin. Nature. (2020) 579:270-3. doi: 10.1038/s41586-020-2012-7

94. Wang FC, Shen BX, He CY, Zhao WC, Nie SL. A network pharmacological study on the clinical efficacy and mechanism of Lianhua Qingwen
Granules on COVID-19. Pharmacol Clini Chin Med. (2020) 36:93-101. doi: 10.13412/j.cnki.zyyl.20200318.001

95. Ling XY, Tao JL, Sun X, Yuan B. Discussion on the material basis and mechanism of Lianhua Qingwen Decoction against coronavirus based on the network pharmacology. Chin Herb Med. (2020) 51:1723-30. doi: 10.7501/j.issn.0253-2670.2020.07.006

96. Du HT, Wang P, Ma QY, Li N, Ding J, Sun TF, et al. Preliminary study on the effective ingredients and mechanism of Huoxiang Zhengqi Decoction in inhibiting the SARS-CoV-2 replication. World Sci Technol Mod Tradit Chin Med. (2020) 22:645-51. doi: 10.11842/wst.20200221002

97. Jo S, Kim H, Kim S, Shin DH, Kim Mu. Characteristics of flavonoids as potent MERS-CoV 3C-like protease inhibitors. Chem Biol Drug Des. (2019) 94:2023-30. doi: 10.1111/cbdd.13604

98. Jo S, Kim S, Shin DH, Kim M-S. Inhibition of SARS-CoV 3CL protease by flavonoids. J Enzyme Inhib Med Chem. (2020) 35:14551. doi: 10.1080/14756366.2019.1690480

99. Wang H, Ma S. The cytokine storm and factors determining the sequence and severity of organ dysfunction in multiple organ dysfunction syndrome. Am J Emerg Med. (2008) 26:711-5. doi: 10.1016/j.ajem.2007.10.031

100. Noroozi R, Branicki W, Pyrc K, Łabaj PP, Pośpiech E, Taheri M, et al. Altered cytokine levels and immune responses in patients with SARS-CoV-2 infection and related conditions. Cytokine. (2020) 133:155143. doi: 10.1016/j.cyto.2020.155143

101. Hu B, Huang S, Yin L. The cytokine storm and COVID-19. J Med Virol. (2020) 93:10. doi: 10.1002/jmv.26232

102. Cron RQ, Behrens EM. Cytokine Storm Syndrome. Cham: Springer (2019). doi: 10.1007/978-3-030-22094-5

103. Channappanavar R, Perlman S, editors. Pathogenic human coronavirus infections: causes and consequences of cytokine storm and immunopathology. Semin Immunopathol. (2017) 39:529-39. doi: 10.1007/s00281-017-0629-X

104. Zhu SY, Li XY, Wei YL, Yang PY, Qin ED. Preliminary study on the inhibition of three Traditional Chinese Medicine prescriptions on SARSrelated Coronavirus in vitro. Biotechnol Newslett. (2003) 14:390-2.

105. Li C, Hu Q, Zhang YX, Wang C. Research progress on pharmacological activity of quercetin. Hubei J Tradit Chin Med. (2018) 40:63-4.

106. Anderson G, Reiter RJ. Melatonin: Roles in influenza, Covid-19, and other viral infections. Rev Med Virol. (2020) 30:e2109. doi: 10.1002/ rmv.2109

107. Zumla A, Hui DS, Azhar EI, Memish ZA, Maeurer M. Reducing mortality from 2019-nCoV: host-directed therapies should be an option. Lancet. (2020) 395:e35-6. doi: 10.1016/S0140-6736(20)30305-6

108. Yuan WY, Wei P, Bao KF, Yao L, Wang XT, Wang SQ, et al. Preliminary study on the effect of Ephedra-Glycyrrhizae herbs on inhibiting allergic asthma. $J$ Nanjing Univ Tradit Chin Med. (2020) 36:41-5.

109. Ji L, Wei $\mathrm{P}$, Wang $\mathrm{C}$, Bao $\mathrm{KF}, \mathrm{Wu} \mathrm{P}$, Li LQ, et al. In vitro antiinflammatory effect of Ephedra-Glycyrrhizae herbs on RAW264. 7 cells induced by lipopolysaccharide. Chin J Exp Formulas. (2017) 18:83-8. doi: 10.13422/j.cnki.syfjx.2017180083

110. Yin XJ. Study on the Anti-Inflammatory Mechanism of Gypsum Based on Calcium and Other Inorganic Elements. Beijing: Beijing University of Chinese Medicine (2019).

111. Zhou XT, Fu LT, Re XT, An HW, Wang YN, Zhu M, et al. Study on antiinflammatory mechanism of bitter almond decoction on adjuvant arthritis rats. Mod J Integr Tradit Chin Western Med. (2011) 20:4198-9.

112. Ravindra NG, Alfajaro MM, Gasque V, Wei J, Filler RB, Huston $\mathrm{NC}$, et al. Single-cell longitudinal analysis of SARS-CoV-2 infection in human bronchial epithelial cells. bioRxiv. (2020) 1-26. doi: 10.1101/2020.05.06.081695

113. Lukassen S, Chua RL, Trefzer T, Kahn NC, Schneider MA, Muley T, et al. SARS-CoV-2 receptor ACE 2 and TMPRSS 2 are primarily expressed in bronchial transient secretory cells. EMBO J. (2020) 39:e105114. doi: 10.15252/embj.2020105114

114. Li J, Liu Y, Zhang X. Murine coronavirus induces type I interferon in oligodendrocytes through recognition by RIG-I and MDA5. J Virol. (2010) 84:6472-82. doi: 10.1128/JVI.00016-10

115. Totura AL, Whitmore A, Agnihothram S, Schäfer A, Katze MG, Heise MT, et al. Toll-like receptor 3 signaling via TRIF contributes to a protective 
innate immune response to severe acute respiratory syndrome coronavirus infection. MBio. (2015) 6:3. doi: 10.1128/mBio.00638-15

116. Li S-W, Wang C-Y, Jou Y-J, Huang S-H, Hsiao L-H, Wan L, et al. SARS coronavirus papain-like protease inhibits the TLR7 signaling pathway through removing Lys63-linked polyubiquitination of TRAF3 and TRAF6. Int J Mol Sci. (2016) 17:678. doi: 10.3390/ijms17050678

117. Channappanavar R, Fett C, Zhao J, Meyerholz DK, Perlman S. Virusspecific memory CD8 T cells provide substantial protection from lethal severe acute respiratory syndrome coronavirus infection. J Virol. (2014) 88:11034-44. doi: 10.1128/JVI.01505-14

118. Bonizzi G, Karin M. The two NF-кB activation pathways and their role in innate and adaptive immunity. Trends Immunol. (2004) 25:2808. doi: 10.1016/j.it.2004.03.008

119. Fu PL, Wang DQ, Li ZJ. Research progress on the pharmacological effects of forsythiaside. J Changchun Univ Tradit Chin Med. (2011) 27:1062-3.

120. Ren Y, Yao M-C, Huo X-Q, Gu Y, Zhu W-X, Qiao Y-J, et al. Study on treatment of "cytokine storm" by anti-2019-nCoV prescriptions based on arachidonic acid metabolic pathway. Zhongguo Zhong Yao Za Zhi. (2020) 45:1225-31. doi: 10.19540/j.cnki.cjcmm.20200224.405

121. Martinez-Micaelo N, González-Abuín N, Ardèvol A, Pinent M, Blay MT. Procyanidins and inflammation: molecular targets and health implications. Biofactors. (2012) 38:257-65. doi: 10.1002/biof.1019

122. Endo T, Ogushi F, Kawano T, Sone S. Comparison of the regulations by Th2-type cytokines of the arachidonic-acid metabolic pathway in human alveolar macrophages and monocytes. Am J Respir Cell Mol Biol. (1998) 19:300-7. doi: 10.1165/ajrcmb.19.2.2915

123. Zhu L, She ZG, Cheng X, Qin JJ, Zhang XJ, Cai J, et al. Association of blood glucose control and outcomes in patients with COVID19 and pre-existing type 2 diabetes. Cell Metab. (2020) 31:106877. doi: 10.1016/j.cmet.2020.04.021

124. Kaur S, Bansal Y, Kumar R, Bansal G. A panoramic review of IL-6: Structure, pathophysiological roles and inhibitors. Bioorg Med Chem. (2020) 28:115327. doi: 10.1016/j.bmc.2020.115327

125. Hutchinson J, Fogarty A, Hubbard R, McKeever T. Global incidence and mortality of idiopathic pulmonary fibrosis: a systematic review. Eur Respir J. (2015) 46:795-806. doi: 10.1183/09031936.00185114
126. Xu X, Chen P, Wang J, Feng J, Zhou H, Li X, et al. Evolution of the novel coronavirus from the ongoing Wuhan outbreak and modeling of its spike protein for risk of human transmission. Sci China Life Sci. (2020) 63:457-60. doi: 10.1007/s11427-0201637-5

127. Li W, Moore MJ, Vasilieva N, Sui J, Wong SK, Berne MA, et al. Angiotensin-converting enzyme 2 is a functional receptor for the SARS coronavirus. Nature. (2003) 426:450-4. doi: 10.1038/nature 02145

128. Fernandez IE, Eickelberg O. New cellular and molecular mechanisms of lung injury and fibrosis in idiopathic pulmonary fibrosis. Lancet. (2012) 380:680-8. doi: 10.1016/S0140-6736(12) 61144-1

129. Hou J, Ma T, Cao H, Chen Y, Wang C, Chen X, et al. TNF-alpha-induced NF-kappaB activation promotes myofibroblast differentiation of LR-MSCs and exacerbates bleomycin-induced pulmonary fibrosis. J Cell Physiol. (2018) 233:2409-19. doi: 10.1002/jcp.26112

130. Liu H, Xue JX, Li X, Ao R, Lu Y. Quercetin liposomes protect against radiation-induced pulmonary injury in a murine model. Oncol Lett. (2013) 6:453-9. doi: 10.3892/ol.2013.1365

131. Wiersinga WJ, Rhodes A, Cheng AC, Peacock SJ, Prescott HC. Pathophysiology, transmission, diagnosis, and treatment of coronavirus disease 2019 (COVID-19): a review. JAMA. (2020) 324:782-93. doi: 10.1001/jama.2020.12839

Conflict of Interest: The authors declare that the research was conducted in the absence of any commercial or financial relationships that could be construed as a potential conflict of interest.

Copyright (C) 2021 Zheng, Jin, Lin, Zhang, Tian, Lian and Tong. This is an open-access article distributed under the terms of the Creative Commons Attribution License (CC $B Y)$. The use, distribution or reproduction in other forums is permitted, provided the original author(s) and the copyright owner(s) are credited and that the original publication in this journal is cited, in accordance with accepted academic practice. No use, distribution or reproduction is permitted which does not comply with these terms. 